\title{
The diagnosis and management of the haematologic manifestations of lupus
}

\begin{abstract}
Haematological manifestations in systemic lupus erythematosus (SLE) are frequently observed. They are diverse and range from mild to severe. Therefore, different treatment approaches are needed from simply keeping vigilant to significant immunosuppression. Most treatment evidence is based on case-reports or small retrospective studies, as few randomized controlled trials have been performed. The development of biological therapy has opened new possible ways to treat the most severe cases but further clinical trials are necessary.

In this review we consider the most common and characteristic haematological manifestations of SLE patients, focusing on their pathogenesis and management.

\section{Highlights}

- Haematological manifestations are common in Systemic Lupus Erythematosus.

- Some of them are part of the classification criteria.

- They can be related to the disease, concomitant blood disorders or iatrogenic.

- These manifestations have a wide range of severity, from mild to life threatening.

- Biological therapy has shown promising results, but more studies are necessary. 


\section{Introduction.}

Haematological manifestations in systemic lupus erythematosus (SLE) are common and diverse. Their frequency varies in different populations[1]. These manifestations can be due to the disease itself, another concomitant disease or iatrogenic. Haemolytic anaemia, leukopaenia, lymphopaenia and thrombocytopaenia are incorporated into both the 1997 update of the 1982 American College of Rheumatology (ACR) [2] and the 2012 Systemic Lupus International Collaborating Clinics (SLICC) [3] classification criteria for SLE.

Most of these manifestations are caused by increased peripheral destruction of blood cells associated with circulating autoantibodies. The major haematological manifestations of SLE are anaemia, leukopaenia, thrombocytopaenia, and the antiphospholipid syndrome (APS). The bone marrow (BM) may also be a target in SLE and features such as myelofibrosis, aplastic anaemia and pure red cell aplasia can also occur. In this review we will consider the pathogenesis and management of these specific manifestations.

2. Red Blood Cell Associated Pathologies

A summary of red blood cell associated pathologies in SLE patients is shown in table 1.

\subsection{Anaemia}

Anaemia is frequent, affecting more than $50 \%$ of patients throughout the course of the disease $[4,5]$.

Anaemia is defined as haemoglobin of less than $12 \mathrm{~g} / \mathrm{dl}$ in women and $13.5 \mathrm{~g} / \mathrm{dl}$ in men [6]. It can be both immune and non-immune mediated in SLE patients.

\subsubsection{Anaemia of Chronic Disease}

2.1.1.1. Introduction

Anaemia of chronic disease (ACD) is the most common type of anaemia in SLE patients, responsible for about one third of the cases[7].

It usually presents as normocytic and normochromic anaemia, with normal or elevated serum ferritin levels and a normal BM.

\subsubsection{Pathogenesis}

The aetiology of ACD in SLE is still not fully understood but it seems to be related to changes in iron homeostasis, inadequate erythropoietin (EPO) response or activity and impaired erythropoiesis. A schematic explanation is presented in figure 1.

\section{Iron Homeostasis}

During inflammation, iron homeostasis is significantly affected, as hepcidin production is regulated by iron. Hepcidin is a hormone produced in the liver that prevents iron from entering into the plasma compartment, by inhibiting iron absorption in the duodenum and its release from hepatocytes and macrophages. It is tightly regulated by the levels of serum iron and its production increases when iron is 
abundant, preventing further absorption and release from stores. Its production diminishes or ceases when iron is deficient [8]. It prevents iron efflux by interacting with ferroportin 1 at the cell surface, leading to internalization and degradation of ferroportin 1 protein [9].

Hepcidin production also seems to be regulated by inflammatory cytokines. IL- 6 induces the production of hepcidin and a consequent hypoferraemic state [10]. Similarly adding IL-6-neutralizing antibodies to hepatocyte cultures ablated hepcidin production. IL-6 levels were significantly higher in SLE patients with active haematological disease and in those patients with anaemia the mean levels of IL-6 were significantly higher than in those patients without it [11]. The Signal Transducer and Activator of Transcription 3 (STAT3) binding site at position -64/-72 of the hepcidin promoter controls IL-6-dependent transcriptional activation and knockdown of STAT3 by RNAi reduces hepcidin mRNA expression, implying that stimuli which activate hepatic STAT3 may also enhance hepcidin expression[12]. Inflammatory immune regulators such as IFN- $\gamma$ and lipopolysaccharides seem to increase monocytes iron acquisition, by stimulating divalent metal transporter 1 (DMT-1) expression and to retain the metal within the cells by inhibiting ferroportin synthesis [13]. In contrast, pro-hepcidin levels do not seem to correlate with disease activity, cytokine levels or serum iron levels in SLE patients [14].

Other cytokines, including TNF- $\alpha$, IFN- $\gamma$ and IL-1, are part of iron homeostasis by reducing the concentration of transferrin receptor on cell surface and increasing ferritin synthesis[9].

\section{Erythropoietin}

The pathogenesis of ACD in different autoimmune diseases is related to reduced EPO activity, due to reduced production and erythroid cells resistance. EPO is fundamental in maintaining an adequate haematocrit level in human blood and its concentration increases with a low haematocrit level and vice versa.

Absolute EPO levels were reduced in SLE patients, even in those without anti-EPO antibodies, but its correlation with haemoglobin and haematocrit variations was maintained [15]. The average levels of EPO in patients with SLE and anaemia did not vary according to the aetiology of anaemia[7].

Anti-EPO antibodies have been detected in SLE patients in some studies $[7,15]$ and were more common in ACD [7]. However, in patients with anti-EPO antibodies there was no correlation between EPO levels and haemoglobin or haematocrit [15]. In contrast, there is conflicting evidence about the relationship between anti-EPO antibodies and the severity of the anaemia. In some studies, the decrease in haemoglobin levels in patients with anti-EPO antibodies was not statistically significant [7] and the anaemia was not more pronounced in SLE patients with antiEPO antibodies (as the EPO levels were also extremely low in these patients there may be some interference in the measurement of EPO due to the antibodies) [15]. In another study of 92 patients with SLE, the prevalence of anti-EPO antibodies in patients with more severe anaemia ( 6 out of 21 patients had a Haemoglobin $<10.0$ 
$\mathrm{g} / \mathrm{dl}$ ) was statistically significantly higher when compared with patients without anaemia and its antibodies titres were also more elevated [5].

Anti-EPO antibodies might also reflect SLE disease activity as they are associated with lower serum complement ( $\mathrm{C} 3$ and $\mathrm{C} 4$ ) and higher anti-dsDNA autoantibody levels[15]. European Consensus Lupus Activity Measurement (ECLAM) scores were statistically significantly higher in patients with anti-EPO antibodies compared to those without them [5].

Impaired erythropoiesis

The mechanisms of impaired erythropoiesis depend on the inhibition of progenitor cells. Several mechanisms are involved, one consists of type I and II interferons inhibiting this proliferation and through caspase and ceramide-dependent pathways also induce apoptosis [16]

Both the sera and IgG isolated from four active SLE patients also suppressed progenitor cell growth in vitro [17].

\subsubsection{Clinical implications}

ACD is a normochromic and normocytic anaemia that is usually mild (haemoglobin 9 to $10 \mathrm{~g} / \mathrm{dl}$ ) to moderate (haemoglobin below $9 \mathrm{~g} / \mathrm{dl}$ ) [7]. The reticulocyte count, the serum concentration of iron and the transferrin saturation are low. In contrast, transferrin and ferritin levels are normal and the latter may be elevated, due to retention in the reticuloendothelial system [18].

As in the evaluation of any cytopaenia, a peripheral blood smear should be performed to distinguish between peripheral destruction in isolated cytopaenias and BM failure in pancytopaenia[19].

To distinguish ACD from iron-deficiency anaemia (IDA), the ferritin concentration level is widely used and if it is $>20 \mu \mathrm{g} / \mathrm{dl}$, IDA is unlikely. A BM biopsy might be performed but its diagnostic yield is low [7]. In another study levels $>30 \mu \mathrm{g} / \mathrm{l}$ gave a positive predictive value of $92 \%$ [20]. Moreover, soluble transferrin receptor (sTfR) has been studied as a possible indicator of iron deficiency, without any connection to chronic disease and inflammation. Patients with ACD+IDA or IDA alone had significantly higher sTfR values [21]. An sTfR Index (sTfR/log ferritin index) above 2 is indicative of true iron deficiency in ACD, while a index below $<1$ suggests functional iron deficiency [16]. A differential diagnostic approach between ACD and IDA is shown in figure 2 .

A nutritional deficiency of iron, folate or vitamin B12 should be considered If the reticulocyte count is inadequate [7]. Measurement of haptoglobin and lactate dehydrogenase to screen for haemolysis and renal function tests should also be performed [16]. Assays to measure hepcidin are not widely available [22]. The evaluation of EPO is not fully established and is only of value when the haemoglobin level is below $10 \mathrm{~g} / \mathrm{dl}$ [18].

\subsubsection{Treatment}


Treatment of the underlying disease is the main goal in SLE patients with ACD [18], but mild cases often do not warrant treatment.

Treatment with an erythropoiesis-promoting agent might benefit patients who are symptomatic. The most widely used are epoetin $\alpha$ (recombinant human EPO) or darbepoetin $\alpha$ which also play a part in treating anaemia of chronic renal insufficiency [19].

Transfusions can be an option in the case of severe or life-threatening anaemia, especially if bleeding conditions are also involved [18]. Long-term transfusions are not recommended due to iron overload and sensitization to HLA antigens [18].

Iron supplementation is not recommended if ferritin level is normal or increased, due to possible adverse outcomes [18], especially in intravenous supplementation, as iron might be linked to atherosclerosis and has an anaphylactic risk [23].

Underlying deficiencies, such as folate or vitamin B12, should be corrected [16].

SLE patients with ACD have a significantly higher disease activity than patients with other types of anaemia, probably due to more frequent concomitant lupus nephritis [7]. Remission of ACD is rare and its recovery is especially slow in patients treated with immunosuppressives [7].

\subsubsection{Iron deficiency anaemia}

\subsubsection{Introduction and Pathogenesis}

IDA is common in SLE patients, affecting about one third of 132 patients with anaemia[7]. It is usually due to chronic gastrointestinal haemorrhage secondary to medication, notably nonsteroidal anti-inflammatory medications and glucocorticoids[24].

\subsubsection{Clinical implications}

IDA patients should be screened for a source of bleeding [19]. It may coexist with $A C D$, leading to a diagnostic challenge, as the serum ferritin is positively influenced by iron loading and inflammation [16].

\subsubsection{Treatment}

After a bleeding source has been excluded or identified and treated, patients may begin oral or intravenous iron supplementation [19]. Iron therapy is the first line treatment for patients with IDA or ACD+IDA [18]. However, oral iron supplementation can lead to inadequate iron absorption in patients with $A C D$, because iron transfer from enterocytes to the circulation is impaired [18].

There are few data about erythropoietic agents and their possible side effects on the course of the underlying disease, as they can interfere with cytokine cascades. If they are introduced, haemoglobin levels should be determined after four weeks of therapy and subsequently at approximately 4 weekly intervals. Iron should be administered simultaneously as there will be no haemoglobin increase if iron deficiency is not corrected [18]. 


\subsubsection{Autoimmune haemolytic anaemia (AIHA)}

\subsubsection{Introduction}

Haemolytic anaemia with reticulocytosis is included in both the ACR and the SLICC classification criteria. Autoimmune haemolytic anaemia (AIHA) involves anti-red blood cell (RBC) antibodies which damage erythrocytes in either a complementdependent or independent manner [19]. AlHA may be the first manifestation of SLE and can appear several years before an SLE diagnosis is made[4]. In one study 27 out of 41 cases of SLE-related AIHA occurred at SLE onset[25].

AlHA can be either primary or secondary. Secondary AIHA is considered a manifestation or a complication of an underlying disorder when: there is an overt immunological link between them; the association of AlHA and the concomitant disease occurs more frequently than the disease itself and the correction of the concomitant disease reverses the AlHA [26].

Its prevalence varies, probably due to the different diagnostic criteria for AlHA. Ten patients out of a cohort of 305 SLE patients had severe haemolytic anaemia (defined by haemoglobin $<8.0 \mathrm{~g} / \mathrm{dl}$, in the presence of a positive direct antiglobulin test (DAT), a raised reticulocyte count and haemoglobin reduction by $3.0 \mathrm{~g} / \mathrm{dl}$ since the last evaluation) [27]. In another cohort of 533 SLE patients, haemolytic anaemia (haemoglobin decrease of $3 \mathrm{~g} / \mathrm{dl}$, rise in conjugated bilirubin and a reticulocyte count $>5 \%)$ was identified in 50 (8\%) patients [28] and in a multi-ethnic cohort of 1251 of female SLE patients 76 patients (6\%) had haemolytic anaemia [29].

\subsubsection{Pathogenesis}

RBC antibodies in SLE are mainly warm-type IgG, but doubts about its antigen specificity remain. The type of antibody is identified, based on the optimal temperature of antigen-antibody reaction. Warm-acting-AlHA and cold-acting-AlHA are distinguished by the optimal temperature of antigen-antibody reactivity [30], the latter being usually mediated by IgM[31]. RBC coated with warm IgG undergo changes in their membranes as they pass through the spleen, resulting in spherocytes, which are removed by phagocytosis [31].

There may be an association between haemolytic anaemia and anticardiolipin antibodies (ACA) [27]. ACA were also statistically significantly more common in SLE patients with AIHA than with IDA [7]. Even in idiopathic AIHA, IgG and IgM ACA are present in higher titres than in normal controls, irrespective of SLE, suggesting it might play a bigger part in RBC destruction [32]. Others have described an increase in ACA IgM levels in SLE patients with AIHA, but no difference in the level of ACA IgG between groups was found[33], while in a study with 41 SLE patients with AIHA IgG, but not IgM, ACA antibodies were associated with AIHA [25]. Antiphospholipid antibodies (aPL) in SLE patients were also related to complement activation and antiRBC activity, with the levels of aPL IgG correlating to hypocomplementaemia and immunoglobulin binding on RBC [34]. Complement levels (both C3 and C4) are also lower in AIHA [7]. 
In NZB mice, the RBC autoantigen for IgG autoantibodies was identified as Band 3 protein, the RBC anion channel [35], but the autoantigen in humans has yet to be identified.

There are conflicting data as to whether anti-dsDNA antibodies are associated with AIHA $[7,27]$.

A possible role for $\mathrm{CD} 55$ and $\mathrm{CD} 59$, glycosylphosphatidylinositol-anchored proteins with complement inhibitory properties, in AIHA has been postulated. The diminished expression of CD55 and, more importantly, CD59 in RBC from many SLE patients with AIHA (and in some patients with primary AIHA), showed no correlation with the presence of aPL in SLE sera. However, acquired deficiency of CD55 and CD59 was seen more consistently in AIHA secondary to SLE than in primary AIHA, probably due to multiple alterations of the immune system. It might play a part in facilitating cell destruction and cytopaenia [36]. Another study confirmed a decreased expression of CD59 in SLE patients with AIHA when compared with SLE patients without it, primary AlHA and normal controls, but CD55 was not significantly decreased in SLE patients with AlHA [37].

\subsubsection{Clinical implications}

Studies of 76 patients with haemolytic anaemia revealed that pericarditis, pleuritis, lupus nephritis and seizures were more common than in those without haemolytic anaemia [29]. Similarly, in another large cohort group (870 SLE patients), leukopaenia, thrombocytopaenia and anti-dsDNA levels were predominant in patients with AlHA[38]. Severe AlHA has also been associated with damage accrual [39].

In one cohort of 305 SLE patients, none of the 10 patients with AlHA died as a direct result of the haematological manifestation [27]. In AlHA, the median time necessary to correct the anaemia is 3 months, and it has a low recurrence rate [7].

\subsubsection{Treatment}

AlHA therapy is mostly based in isolated case reports and a few retrospective studies. There is a lack of established definitions of treatment goals, especially when to switch to second-line therapies. There are few clinical trials of first-line treatments. Many of the available studies were conducted in idiopathic AIHA and their results extrapolated to SLE patients with AIHA [31].

Treatment options are varied, but one study showed oral prednisone (mean dose $1 \mathrm{mg} / \mathrm{kg}$ ) was used as the first-line treatment in $50 \%$ of patients and high dose methylprednisolone $(1.5 \mathrm{mg} / \mathrm{kg} / \mathrm{day})$ in the other $50 \%$ [40]. Twenty five per cent of patients with primary AIHA require at least 2 types of therapy, 13\% require 3 and $4 \%$ $>4$ types [41].

The treatment usually used is glucocorticoids as first line of treatment (prednisone up to $1 \mathrm{mg} / \mathrm{kg} / \mathrm{day}$ ) and the haemoglobin response usually takes up to 3 weeks, [31]. When a sustained response is achieved, the dosage should be slowly tapered, although the optimal rate has not been established. If a patient fails to respond (defined by lack of response after 3 weeks treatment), significant doses of oral 
prednisolone (around $15 \mathrm{mg} /$ day) plus second line therapy are likely to be required [31]. In these cases, both conventional immunosuppressive therapy and splenectomy can be used. The pros and cons of the various therapeutic options are shown in Table 2.

\section{New therapies}

There have been some case reports of new therapies or combinations in the management of patients with mostly primary AlHA. Rituximab (RTX), which binds the CD20 molecule present on many $B$ cells, and alemtuzumab, a monoclonal antibody that binds to CD52, were used in 21 consecutive adult patients, 8 of whom had AIHA, and beneficial responses were observed in all patients. The median duration of complete remisison was 46 weeks and 3 of 8 patients with AlHA maintained complete remission at 33,46 , and 89 weeks. CD4+ T cells were still at low levels at week 24, whereas B and NK cells partially recovered to basal levels [42].

In a 29-year-old woman with warm IgM AlHA secondary to eosinophilic granulomatosis with polyangeiitis, eculizumab and RTX was successfully administered after treatment failure to 3 previous treatments. A single administration of eculizumab $600 \mathrm{mg}$ IV, a humanized monoclonal antibody against terminal complement $\mathrm{C} 5$, lead to a $3 \mathrm{~g} / \mathrm{dl}$ increase in haemoglobin levels, without further need to treatment or transfusion. Subsequently, RTX was successfully administered as maintenance therapy[43]. In 64-year-old female patient with AIHA, secondary diffuse large B-cell non-Hodgkin lymphoma, was given C1 esterase inhibitor ( $\mathrm{C} 1-\mathrm{INH})$ to enhance the efficacy of the RBC transfusion. This lead to attenuated complement deposition on RBCs and reduction in haemolysis rate. Therefore, the response to RBC transfusion was higher and more sustained over time [44].

\subsubsection{Thrombotic microangiopathic haemolytic anaemia}

In 1952, the name thrombotic microangiopathic haemolytic anaemia (TMHA) was introduced by Symmers to describe a diverse clinical presentation with localized or diffuse microvascular thrombosis, thrombocytopaenia, microangiopathic haemolytic anaemia, but with a negative Coombs' test. Simultaneously, patients could have fever, neurological symptoms, and kidney involvement. [45]

Its physiopathology is not fully understood, but it might be associated with aPL and TMHA could be a manifestation of APS. In a review, $61 \%$ of patients were categorized as having primary APS, and TMHA was the first manifestation of the APS in $93 \%$ of them. Thus, aPL might be a part of the development of TMHA in patients either with or without SLE. [46] In another study with 15 patients with TMHA (out of 114 SLE patients), the presence of anti-Sm and anti-RNP antibodies was associated with a higher incidence of TMHA[47].

The differential diagnosis of TMHA in SLE patients is extensive and challenging, as it can be a presentation of malignant hypertension, APS, catastrophic APS (cAPS), TTP or even a SLE flare. TTP and malignant hypertension have consumptive thrombocytopaenia with TMHA, in contrast to the immune-mediated processes seen 
in APS and SLE. [48] In a study, 15 out of 114 SLE patients had TMHA and all of whom had a negative DAT result, with mild thrombocytopaenia and anaemia [47].

Patients should be systematically screened for lupus anticoagulant and ACA due to the association between TMHA and APS [46].

Disease activity as assessed by the SLE Disease Activity Index (SLEDAI) score was increased in patients exhibiting features of TMHA.[47]

Choosing the optimal treatment is complicated due to the difficult differential diagnosis and often therapy for all possible diagnoses is given simultaneously [48]. In one study 7 out of 15 patients responded to methylprednisolone alone, 4 responded to methylprednisolone with plasmapheresis, 2 to methylprednisolone and immunosuppressive therapy, and 2 methylprednisolone with both plasmapheresis and immunosuppressive therapy [47].

\subsubsection{Pure red cell aplasia or hypoplastic anaemia}

Pure red cell aplasia (PRCA) is characterized by normochromic normocytic anaemia and reticulocytopaenia, with aplasia or severe hypoplasia of the red cell line, while leukocyte and megakaryocyte lines in the BM remain normal [49]. In most cases, PRCA is diagnosed concomitantly or shortly after SLE diagnosis [50].

The pathogenesis of PRCA is varied including genetic defects affecting the erythropoietic lineage, viral infections (such as parvovirus B19) and autoimmunerelated factors [49].

As previously described in ACD, anti-EPO antibodies can also lead to PRCA by neutralizing erythropoiesis [51]. It has also been shown that sera from SLE patients can suppress granulocytic and erythroid colony formation in vitro. The IgG fraction has been isolated from these sera and its action is probably related to binding CD34+ haematopoietic progenitor cells, but not to CD33+ cells [17]. However, in vivo reports are conflicting [52].

The disease responds to prednisone in the majority of cases, but tapering is difficult [50].

Aplastic anaemia is characterized by pancytopaenia with a low reticulocyte count and hypocellular BM. It is rare in SLE [53].

It is thought that antibodies to BM progenitor cells lead to BM aplasia and resultant pancytopaenia. This idea is supported by data showing that the suppression of colony forming units-granulocyte monocyte (CFU-GM) was mediated by the serum or IgG complement-dependent fraction of a SLE patient's serum in the acute phase. In contrast the IgG fraction obtained six weeks after that acute phase showed no CFU-GM suppression[54]. Knowing that cytopaenias may occur on the basis of inhibited myelopoiesis in SLE flares should lead to ANA screening in patients with BM acellularity of unknown cause [55].

Some case reports describe the use of cyclosporine (CSA) (300 mg/day) [53] and CYC in refractory cases with remarkable success[56]. 


\subsubsection{Others}

SLE patients can obviously be affected by nutritional deficiency anaemia. Low serum vitamin B12 levels have been reported in SLE patients [57]. Few cases of SLE patients with pernicious anaemia have been described [58-60].

\section{White Cell Associated Pathologies}

A summary of white cell associated pathologies in SLE patients can be found in table 3.

\subsection{Leukopaenia}

In the 1997 update of the ACR criteria leukopaenia is defined as levels $<4000 / \mathrm{mm}^{3}$ on at least 2 occasions and lymphopaenia as levels $<1500 / \mathrm{mm}^{3}$ on at least 2 occasions [61]. Similarly, in the SLICC classification criteria, leukopaenia $\left(<4000 / \mathrm{mm}^{3}\right.$ on at least one occasion) and lymphopaenia $\left(<1000 / \mathrm{mm}^{3}\right.$ at least once) are also part of the SLE classification criteria [3].

\subsubsection{Neutropaenia}

Neutropaenia in autoimmune diseases can be either primary or secondary. Antineutrophil antibodies can induce neutropaenia, which may also result from peripheral sequestration, BM inhibition, or apoptosis. The specific target of the autoantibodies is unknown and it is quite common for these cases to develop thrombocytopaenia or haemolytic anaemia simultaneously [62].

In SLE patients, thrombocytopaenia, central nervous system involvement and immunosuppressive medications were identified as independent risk factors for developing neutropaenia and, in some cases, the BM showed signs of myeloid hyperplasia, suggesting that BM failure is not the cause of neutropaenia [63].

Another study linked severe neutropaenia with the presence of IgG on myelocytes and promyelocytes, as well as mature cells. Patients with moderate neutropaenia had IgG only on neutrophils and metamyelocytes whereas in the control group IgG did not deposit on peripheral blood or earlier precursors [64]. There was a significant decrease in the number of granulocytic precursors cells (CFU-C) in SLE patients. In neutropaenic patients the numbers of CFU-C were lower than in non-neutropaenic patients, suggesting that a decrease in BM CFU-C plays a part in neutropaenia in SLE. Simultaneously, T cells from SLE patients inhibited in vitro CFU-C colony formation in the BM from healthy individuals [65].

It is also likely that an autoimmune aetiology also contributes directly to neutropaenia in SLE patients. There is an inverse relationship between the neutrophil count and the ability of patients' sera to opsonize granulocytes for recognition and clearance by human monocytes. The level of membrane-binding IgG significantly correlated with opsonic activity while the level of Clq-binding immune complexes was also elevated in some patients and correlated with opsonic activity[66]. Another study revealed that neutrophil count significantly correlates negatively with the C3-binding ability in patients with SLE [67]. These data suggest the possibility of complement activation, driven by antineutrophil antibodies. 
In a study of 72 SLE patients, anti-Ro/SSA antibodies were linked to a lower average neutrophil count than those lacking these antibodies. The sera from the former bound neutrophils more than either sera from anti-Ro negative SLE patients or from healthy controls. It was also shown that anti-Ro antibody can fix complement on the surface of neutrophils, but its antigen was a 64-kD protein instead of 60-kD Ro[68].

In SLE patients with neutropaenia, the possibility of concomitant infection and medication side effects, particularly immunosuppressants must be considered [31, 63]. BM aspiration and biopsy may be necessary in acute and severe cases[31].

Treating the underlying condition and close monitoring are sufficient in most patients. Neutropaenia is only treated specifically if it is severe with concomitant infection [30]. In these cases, there are some limited data regarding the possible benefit of human recombinant granulocyte colony stimulating factor (rhG-CSF). There is a case report of severe neutropaenia in SLE patient who was treated with rhG-CSF (100 pg/d, 5 days) together with methylprednisolone pulse therapy, with a good outcome [69]. There is also a small study of 9 SLE patients with refractory infection who received rhG-CSF without corticosteroids. The average PMN count increased in two days, but 3 patients had a haematological flare [70].

\subsubsection{Lymphopaenia}

Out of 158 SLE patients with active disease studied from the time of diagnosis, lymphopaenia was present in $75 \%$. After disease reactivation, another $18 \%$ also developed lymphopaenia[71].

Autoantibodies to lymphocytes seem to be part of the pathogenesis as titers of IgG antibodies to lymphocytes (but not IgM) have been shown to correlate inversely with lymphocyte and complement levels [72]. Another study reported that the sensitivity and specificity of IgG antilymphocyte antibodies in SLE was $42.3 \%$ and $96.7 \%$, respectively and the antibodies were independently associated with lymphopaenia [73]. In a study conducted in human $T$ and B cell lines as antigens (P12 (CD4-, CD8+), Jurkat (CD4-, CD8-), Hut78 (CD4+, CD8-) and Wa (B cell), respectively), serum antibody titres were higher than those in normal control subjects and it seems that autoantibodies react with both $T$ and $B$ cells [72]. The titers of antiRo/SSA, anti-dsDNA and anti-ribosomal $\mathrm{P}$ were also more elevated in the lymphopaenic group. No correlation was found for anti-La/SSB, anti-RNP, anti-Sm or anti-histones [74].

Antibodies against galectin 8 (Gal-8) are highly specific as they do not cross-react with other galectins (multifunctional proteins which mediate cell contact, migration, growth and apoptosis), and they are also associated with lymphopaenia in SLE patients, notably in those with a malar rash. However, these antibodies are also present in rheumatoid arthritis and sepsis [75].

As far as peripheral $T$ cells are concerned, a reduction in T cell numbers relates to the presence of anti-T cell antibodies especially in acutely ill patients. B cells numbers, measured through lymphocytes bearing surface Ig, also frequently correlate with disease activity[76]. In patients with different subtypes of lupus erythematosus, T- 
helper lymphocyte cells are more often diminished in patients with more severe presentations [77].

The CD55 and CD59 proteins have complement inhibitory properties. In SLE patients CD55 surface density was higher in CD19+ cells than in CD3+ cells, while CD 59 was higher in CD3+ cells. In SLE patients with lymphopaenia, CD55 and CD59 were less expressed in both CD3+ and CD19+ lymphocytes [74]. The surface expression of Fas antigen is also higher on both naïve and memory CD+ and CD8+ T cells from SLE patients, however only CD4+ cells levels have an inverse correlation with the expression of Fas antigen [78].

CD27+ memory B cells seem to be the most common population in SLE, but in lower numbers than in healthy controls. After immunosuppressive therapy, CD27+ cells remain stable, while naïve $C D 27-B$ cells and $C D 27^{\text {high }}$ plasma cells are diminished [79].

The relationship between disease activity, as measured by SLEDAI and lymphopaenia, has been studied. At the beginning of one study SLEDAI score correlated positively with lymphopaenia (84) and after 1 year, a high SLEDAI score was similarly associated with lymphopaenia. Nonetheless, after 2 years the SLEDAI score only correlated with anti-dsDNA antibodies. Lymphopaenia is, together with other haematological changes, a predictor of flare during the following year [80]. SLEDAI levels were significantly higher in SLE patiens with anti-lymphocytic antibodies [73].

As for neutropaenia, the underlying disease should be managed appropriately. Although controversial [81], prophylactic antibiotic therapy against Pneumocystis jiroveci might be considered in more severe cases of lymphopaenia and it seems to have a good safety profile [82].

\subsection{Leukocytosis}

The major effect of glucocorticoids on neutrophils appears to be the inhibition of neutrophil adhesion to endothelial cells, which leads to neutrophilia [83]. Obviously, the main reason to an increased leukocyte count is infection, which requires swift action in terms of diagnosis and treatment.

4. Platelet associated pathologies

A summary of platelet associated pathologies in SLE patients can be found in table 4.

\subsection{Thrombocytopaenia}

\subsubsection{Introduction}

Thrombocytopaenia is a frequent manifestation in SLE patients though it is often mild. Three different mechanisms are linked to thrombocytopaenia: impaired production in the BM, sequestration in the spleen and accelerated destruction [31]. The most common is immune mediated platelet destruction in the peripheral circulation by antiplatelet antibodies [84-86].

\subsubsection{SLE immune Thrombocytopaenia}

4.1.2.1. Introduction 
Immune thrombocytopaenia is an immune-mediated disorder occurring as a primary event (P-ITP) characterized by isolated thrombocytopaenia or associated with other conditions, such as SLE (SLE immune thrombocytopaenia) [87].

SLE immune thrombocytopaenia is a common clinical manifestation, ranging from 7 to $30 \%$ [88-91], which is defined as a platelet count $<100 \times 10^{9} / \mathrm{mm}^{3}$ without any other identifiable cause $[2,3,61]$. In a large single-centre cohort study 50 out of 632 patients had thrombocytopaenia [92]. Of these 50 patients, $54 \%$ had platelet counts of 50 to $100 \times 10^{9} / \mathrm{mm}^{3}, 18 \%$ had counts between 20 and $50 \times 10^{9} / \mathrm{mm}^{3}$, and $28 \%$ had a platelet count of less than $20 \times 10^{9} / \mathrm{mm}^{3}$.

\subsubsection{Pathogenesis}

Mechanisms implicated in immune SLE thrombocytopaenia are summarized in figure 3.

\subsection{Antiplatelet Autontibodies}

Antiplatelet autoantibodies bind to platelets, leading to platelet phagocytosis in the spleen. This is often associated with a normal or increased number of megakaryocytes in the BM. These autoantibodies can be found in both P-ITP and SLE immune thrombocytopaenia, but immunological differences have been described between the two conditions [31] and even among SLE patients with immune thrombocytopaenia there are differences in the autoimmunity directed against platelets [93].

Antiplatelet autoantibodies are present up to $60 \%$ of SLE patients, the majority being IgG (60\%) (23\% are IgM) [94, 95]. In P-ITP, the antigens for antiplatelet antibodies are glycoprotein Ilb/IIla (Gpllb/IIla) and membrane glycoprotein ( $\alpha$ llaß3integrin), and they can also be seen in SLE patients. In addition, glycoprotein la/lla (Gpla/lla) and glycoprotein IbIX (GPIbIX) antigens have also been described in SLE immune thrombocytopaenia. The presence of antiplatelet antibodies does not automatically lead to the development of thrombocytopaenia. Other factors for thrombocytopaenia development in seropositive patients are active disease and complement activation [92].

\subsection{Other causes of immune-related platelet destruction}

\section{The role of antiphospholipid antibodies}

SLE patients with thrombocytopaenia are more often positive for lupus anticoagulant and higher levels of IgM ACA have been related to a potential role of aPL in its pathogenesis. López-Soto et al related ACA, antiphosphatidic, antiphosphoserine, antiphosphoinositol and lupus anticoagulant antibodies with thrombocytopaenia [96]. Moreover, the presence of ACA has been found to increase the relative risk for thrombocytopaenia four-fold [97]. Nevertheless, the exact pathophysiology of the relationship between the presence of aPL and thrombocytopaenia remains unknown.

The role of antibodies against thrombopoietin and antibodies against thrombopoietin receptor 
Although immune thrombocytopaenia is often related to a normal or increased number of megakaryocytes, amegakaryocytic hypoplasia has been described in a few cases [98-100]. This feature has been related to antibodies against thrombopoietin (TPO) and against the TPO receptor (c-mpl receptor). The binding of TPO (the c-mpl ligand) to its receptor is the key regulator of platelet production. SLE patients have higher serum levels of TPO, as well as autoantibodies against TPO and its receptor. Moreover, the presence of autoantibodies against the TPO receptor may be associated with a poorer response to steroids [86, 101, 102]. Despite these findings, the exact role of these antibodies in the pathogenesis of lupus thrombocytopaenia is uncertain.

\section{The role of genetics}

A genetic contribution to thrombocytopaenia was suggested in a study of 159 SLE coaffected siblings, in which the risk of thrombocytopaenia was increased when compared with a cohort of 709 non-related SLE patients [103]. A genetic linkage genetic linkage at 1q22 and 11p13 was found and also correlated with a severe SLE form $[104,105]$. However, it remains unclear whether these findings are directly related to the mechanism of thrombocytopaenia or a marker of severe SLE.

\subsubsection{Clinical Implications}

The presentation of immune thrombocytopaenia in SLE patients can be divided in three main forms: acute, chronic and prior P-ITP. An overview of these manifestations can be found in table 5 . The acute form occurs as part of a generalised exacerbation of SLE. It is usually severe (platelet count $<25 \times 10^{9} / \mathrm{mm}^{3}$ ) and may be associated with life-threatening haemorrhage risk. It often responds to steroid treatment and improves when the SLE comes under control. The chronic form is more common and it rarely causes major symptoms. It is not related to disease activity. Although it is less responsive to steroid therapy, this is not a major concern because the platelet count is usually modestly decreased $\left(75-125 \times 10^{9} / \mathrm{mm}^{3}\right)$ and it may not require specific therapy. P-ITP can precede SLE diagnosis in $3 \%$ to $16 \%$ of patients and may occur up to 10 years before SLE becomes clinically apparent[106].

In most patients, thrombocytopaenia follows a benign course, platelet counts down to $30 \times 10^{9} / \mathrm{mm}^{3}$ rarely cause more than a prolonged bleeding time. However counts of less than $20 \times 10^{9} / \mathrm{mm}^{3}$ are usually associated with petechiae, purpura, ecchymosis, epistaxis and other clinical bleeding. Severe thrombocytopaenia is uncommon so major bleeding only occurs in a minority of patients. It can be fatal if it involves the central nervous system or the gastrointestinal tract [87].

The presence of thrombocytopaenia is an important independent risk factor for mortality in SLE. This has been validated for many, though not all European, North ans South American, Hispanic, Chinese and African American patients with SLE [107, 108]. SLE patients with late-onset thrombocytopaenia have a greater risk than those whose thrombocytopaenia occurred early in the course of their disease [94].

SLE patients with thrombocytopaenia are also more likely to have significant organ damage, such as heart, kidney and central nervous system involvement $[90,92,109$ - 
111]. Thrombocytopaenia has also been correlated with low levels of complement (C3), higher SLE disease activity, haemolytic anaemia and the presence of other cytopaenias [27, 92].

\subsubsection{Treatment}

When treatment is required, the approach is similar to P-ITP. Immune thrombocytopaenia treatment is usually recommended for symptomatic patients with platelet counts $<25 \times 10^{9} / \mathrm{mm}^{3}$ [112]. Platelet transfusions should be avoided in immune thrombocytopaenia and only considered when the platelet count is less than $10 \times 10^{9} / \mathrm{mm}^{3}$ or invasive procedures are needed [113].

Conventionally, high-dose glucocorticoids are considered first-line therapy in severe thrombocytopaenia $[114,115]$. Hydroxychloroquine (HCQ) or danazol can be added in refractory patients or in an effort to taper glucocorticoids. If there is no significant improvement within three weeks or the side effects are intolerable, other immunosuppressive treatments should be considered [113], such as azathioprine (AZA), CSA, CYC, vincristine or vinblastine, but they have limited success [116]. Splenectomy used to be an alternative therapeutical option for SLE patients with refractory immune thrombocytopaenia [117-119]. However, in addition to concerns about high rate of infection [120] and the long-term outcome [119], the introduction of RTX has rendered this operation almost obsolete. RTX may be used in both SLE immune thrombocytopaenia and P-ITP. It is preferred to splenectomy in SLE patients, because its B lymphocyte depleting approach may be beneficial for other manifestations of SLE [121]. Moreover, a significant decrease of antiplatelet antibodies, especially IgG isotype, occurs after RTX treatment [122].

In emergency situations several therapies are used simultaneously, such as highdose glucocorticoids and IVIg. IL-11 could be considered if the patient does not response adequately to the first two choices. Plasmapheresis can be effective in patients with refractory thrombocytopaenia and active bleeding [123].

Additional treatments such as other anti-other monoclonal therapies, including at CD40L, targeting co-stimulatory molecules (such as CTLA4-Ig) and immune complexes (such as intravenous anti-D) may be considered though there are few data.

The main treatments available with their targets can be found in figure 4 , and a summary of their indications in table 6.

4.1.3. Thrombocytopaenic thrombotic purpura.

4.1.3.1. Introduction

TTP is a thrombotic microangiopathy first described in 1924 by Moskowitz. It is characterized by the pathological findings of platelet thrombi in the microcirculation of several organs. Patients with TTP typically develop microangiopathic haemolytic anaemia, thrombocytopaenia and organ failure of variable severity 
Various clinical subtypes of TTP exist, including hereditary forms. TTP can be primary/idiopathic or secondary/acquired, associated with other conditions (autoimmune disorders, malignancies...) [124]. A number of autoimmune disorders have been reported in association with TTP and SLE is the most frequent autoimmune disease associated with TTP [125]. However, TTP is a rare complication in the context of SLE and generally occurs in patients with severe lupus activity and renal involvement [126]. The estimated incidence of TTP in SLE is $2-3 \%$ [127]. However, post-mortem examination of patients suggest an even higher incidence [128].

\subsubsection{Pathogenesis}

TTP can result from a severe deficiency in ADAMTS13 (a disintegrin and metalloprotease with ThromboSpondin type 1 repeats) [129] but additional genetic and/or environmental triggers are thought to be required to trigger acute illness. ADAMTS13 limits platelet aggregation by cleaving Von Willebrand factor (VWF) multimers into less adhesive forms. Its deficiency leads to persistence of ultra-large VWF (ULVWF) multimers, widespread formation of microvascular platelet thrombi, and subsequent microangiopathic haemolytic anaemia and organ ischaemia [130]. Severe ADAMTS13 deficiency in acquired TTP is caused by autoantibodies against ADAMTS13, which either neutralize ADAMTS13 activity or accelerate its clearance $[131,132]$. High titres of anti-ADAMTS13 antibodies may be associated with refractory disease in SLE patients [133].

Anti-nuclear (ANA), anti-Ro and anti-dsDNA antibodies may develop many years before the diagnosis of SLE [134]. This association has been also published in a TTP population, where anti-Ro and anti-dsDNA antibodies at the time of TTP diagnosis were significant risk factors for the later development of SLE [125]. This finding could lead to early identification of an associated autoimmune disease allowing early targeted management.

The predisposing role of aPL in TTP is controversial and remains unclear $[125,135]$.

\subsubsection{Clinical implications}

Prominent clinical features of TPP include severe thrombocytopaenia $\left(<50 \times 10 \mathrm{~mm}^{3}\right)$, microangiopathic haemolytic anaemia, fever, renal failure and neurological dysfunction. There is considerable overlap between the characteristic features of TTP and some SLE features [136]. Although the diagnosis of SLE usually precedes that of TTP [137], it can develop simultaneously or after the diagnosis of TTP [126, 138142]. In paediatric populations, there are some data that suggest that primary TTP may evolve to SLE [143].

Prolonged follow-up is necessary after an acute primary TTP, especially when anti-Ro or anti-dsDNA antibodies are present at the time of TTP diagnosis [125].

TTP in SLE is often life-threatening and in spite of earlier and more aggressive therapy in SLE patients, the mortality is higher and the time to complete remission longer than in idiopathic TTP, suggesting a refractory and more severe disease [126, 144]. 


\subsubsection{Treatment}

Plasmapheresis can successfully remove the autoantibodies and replenish ADAMTS13, thereby restoring functional ADAMTS13 levels. Since its introduction, mortality from TTP has decreased dramatically from $90 \%$ to $25 \%$ [145]. Hence, it is the first-line treatment in TTP $[146,147]$. However, SLE patients seem more refractory to this treatment [126].

In case of a poor response to plasmapheresis in SLE patients with TTP, other treatments to be considered include high-dose glucocorticoid, CYC and IVIg [138, 148].

RTX has been successfully used in refractory TTP in SLE [136, 149-153]. Since TTP can precede SLE onset, it has been hypothesized that if RTX was used for the treatment of TTP this could prevent or delay the appearance of overt clinical SLE. However, the results of a cross-sectional study do not support this hypothesis since acute TTP patients previously treated with RTX did not have a lower incidence of autoimmune disorders than those not given the treatment [125].

\subsubsection{Other causes of thrombocytopaenia in SLE patients}

Drug therapy used in SLE can induce thrombocytopaenia often by leading to impaired production of platelets in the $B M$. This is well recognized with drugs such as AZA and CYC and rarely with drugs such as $\mathrm{HCQ}, \mathrm{MMF}$ and CSA.

Platelet consumption may also occur in association with microangiopathic haemolytic anaemia. Pseudo-thrombocytopaenia, secondary to platelet aggregation or platelet adherence to leukocytes, must always be considered and excluded by examining the peripheral smear [31]. BM examination, especially in older patients, should also be considered to rule out occult myelodysplasia.

\subsection{Thrombocytosis.}

Platelet count $>400 \times 10^{9} / \mathrm{mm}^{3}$ constitutes thrombocytosis. It is much less common than thrombocytopaenia in SLE. It may occur as a result of active disease or reactive to the underlying inflammatory process. Hyposplenism (or functional aesplenia or autosplenectomy) has been reported as a cause of thrombocytosis in SLE patients $[154,155]$ and may be related with aPL or with associated APS $[156,157]$.

\section{Pancytopaenia.}

There are a number of potential causes of pancytopaenia in SLE patients, notably drugs, peripheral destruction, other concomitant diseases, autoimmune myelofibrosis and uncommon causes such as macrophage activation syndrome (MAS).

However, when a SLE patient presents with a reduced number of red cells, leukocytes and platelets, this often suggests haematopoietic failure as the result of immune-mediated BM damage. When performing a BM biopsy in SLE patients with an unexplained pancytopaenia, hypocellularity was described as a predominant finding $[158,159]$. 


\subsection{Autoimmune myelofibrosis and SLE.}

\subsubsection{Introduction}

Myelofibrosis is rare and characterized by deposition of reticulin fibres in the BM stroma, which usually occurs in response to clonal proliferation of myeloid stem cells in myeloproliferative disorders [160]. It has been described in association with several haematologic malignancies and metastatic solid malignancies [161, 162]. However, it can be also a manifestation of endocrine or inflammatory conditions. The association between myelofibrosis and autoimmune disorders was first described in 1978 [163]. Twenty years later Paquette et al [164] proposed and defined the term autoimmune myelofibrosis. Since then, around 40 cases have been reported in association with SLE [165]. The spleen is often, but not always, enlarged. However, this pathology may be more common, with cases being incorrectly characterized as blood peripheral cytopaenias in patients previously diagnosed with SLE, and cases being misdiagnosed as primary myelofibrosis in patients not previously diagnosed with SLE [165].

\subsubsection{Pathogenesis}

The aetiology of autoimmune myelofibrosis remains unknown. One hypothesis proposes that circulating autoantibodies and immune complexes of SLE stimulate the megakaryocytes Fc-receptors, resulting in the release of growth factors.

Platelet-derived growth factor, found in megakaryocytes and platelets, stimulates fibroblast growth [160]. Consequently, transforming growth factor $\beta$ and epidermal growth factor promote collagen synthesis [166]. Fibroblast proliferation, increased collagen synthesis or altered collagen turnover lead to an increase in reticulin, which is deposited in BM stroma [167]. It has been suggested that autoantibodies against CD34+ and cytotoxic T cells act as causal agents in BM damage and also perpetuate damage [168].

\subsubsection{Clinical implications}

Autoimmune myelofibrosis can be diagnosed at the time or after the diagnosis of SLE. Most patients present with either bicytopaenia (anaemia and thrombocytopaenia) or pancytopaenia [165]. It is more frequent in younger patients than primary myelofibrosis (median age 29 years vs 66 years in primary myelofibrosis) [30,165, 169]. The majority of case reports are among Caucasian or Mexican-American, followed by African-American and Arab patients [30, 165].

BM biopsy in patients with suspected immune SLE myelofibrosis is virtually indistinguishable from primary myelofibrosis [167]. The biopsy of immune SLE myelofibrosis usually shows increased reticulin fibres and fibroblasts whereas significant marrow fibrosis is not often seen. However, the finding of BM reticulin fibrosis in a SLE patient should not immediately prompt the diagnosis of autoimmune myelofibrosis. Mild degrees of reticulin fibrosis can be observed in other pathologies such as immune thrombocytopaenia and may be found in many patients with SLE when routine BM biopsies are performed (132). Some authors conclude that BM biopsy should only be recommended if cytopaenia does not recover after conventional therapy [158]. 
The prognosis of autoimmune myelofibrosis in SLE patients is generally favourable and usually responds well to first line treatment [165]. However, in patients who eventually do not respond to treatment, transformation to acute leukaemia or other complications may occur.

\subsubsection{Treatment}

Glucocorticoids are the first line of treatment and often very successful unlike the situation with primary myelofibrosis. Early diagnosis and prompt treatment can lead to an improvement in the cytopaenia and in the BM architecture with a resolution of the pathology. However, well-established myelofibrosis has a poorer response and may be fatal [165].

In primary myelofibrosis, activating mutations in Janus kinase (JAK) have been recognized to play an important part in its pathogenesis [170]. A JAK inhibitor, Ruxolitinib, was shown to be effective in the treatment of primary myelofibrosis [171-173]. However, these mutations have not been found in immune SLE myelofibrosis and Rituxinib has not been used for its treatment as far as we are aware.

IVIg proved to be effective in some patients $[165,174]$ and there is one case report with combined treatment of glucocorticoids and MMF which reports a good outcome[175].

\subsection{Other causes of pancytopaenia}

5.2.1. Secondary macrophage activation syndrome in SLE patients.

MAS is characterized by increased proliferation and activation of benign macrophages and T cells, with increased secretion of proinflammatory cytokines[176]. It is classified as primary/familial and secondary/reactive in the context of malignancy, systemic autoimmunity, infection, or drug-hypersensitivity reaction.

Secondary MAS is a rare cause of cytopaenia in SLE [176] but may be lifethreatening. Although it is more frequent in paediatric populations, it also can occur in adults where it is usually more severe [177]. Given its complex clinical features, MAS can be missed in SLE patients $[176,178]$. Secondary MAS in SLE patients is often present at disease onset. However, it can be triggered by an infection (mostly viral) and, sometimes, both flare and infection coexist in SLE patients [179].

Its pathogenesis remains unclear. It has been proposed that autoantibodies and immune complexes sensitize BM cells to macrophages, which subsequently engage in uncontrolled phagocytosis. Moreover, T cell-derived cytokines (IL-1, IL-6, IFN- $\gamma$, TNF- $\alpha$ ) enhance the inappropriate activation of macrophages. This cytokine storm might be a result of primary uncontrolled T-cell activation in SLE patients [31].

It is often manifested with pancytopaenia associated to hyperferritinaemia, anti-DNA antibodies, low C-reactive protein ( $<30 \mathrm{mg} / \mathrm{L}$ ), a falling erythrocyte sedimentation rate (ESR), hypocomplementaemia and elevated triglycerides. Its clinical characteristics include non-remitting high-fever, weight loss, arthritis, pericarditis, 
rash, myocarditis, nephritis, splenomegaly, hepatomegaly and lymphadenopathy [180].

The therapeutic strategies for MAS in SLE are not well established and to treat this syndrome effectively, it is vital to identify the trigger. In SLE patients in which MAS is driven by disease activity in the absence of obvious infection, immunosuppressive therapy is the main treatment, including high-dose glucocorticoids, CYC or CSA [179, 181]. When a flare is present along with a concomitant infection, IVIg in addition to anti-infective agents should be considered, as well as glucocorticoids [182]. If it is triggered by an obvious microbial infection, antibiotics should be initiated and immunosuppressive therapy decreased as much as possible.

\section{Evans syndrome.}

Evans syndrome is characterised by the presence of autoimmune haemolytic anaemia (AIHA) associated with concomitant or sequential development of autoimmune thrombocytopaenia [183]. Therefore, when a SLE patient is diagnosed with AIHA a carefully monitoring of the platelet count is mandatory. However, secondary Evans syndrome in SLE patients is rare and it often precedes the onset of SLE [184]. High-dose glucocorticoids might be used, but once they are stopped or tapered, relapses are common. In refractory cases, other drugs used in either AlHA or immune SLE thrombocytopaenia have been successfully used, such as danazol [185], romiplostim [186] and RTX [187].

\section{Haemostasis alterations}

\subsection{Thrombosis in SLE patients.}

Thrombosis causes substantial morbidity and mortality in SLE patients. In a 10-year prospective cohort study, thrombosis was the second most frequent cause of death [188]. Moreover, SLE patients have an increased risk of thrombosis, even in the absence of aPL which increases the risk even further [94]. Thrombotic complications can be found in $>10 \%$ of SLE patients and this risk increases up to $50 \%$ in patients with lupus anticoagulant $[189,190]$. Therefore a risk-stratified approach to thrombosis risk factors is required in order to prevent their occurrence.

The pathogenesis of thrombosis in SLE is multifactorial and several risk factors have been identified [191]. Three major conditions have been described historically: hypercoagulability, premature atherosclerosis and vasculitis[192]. A hypercoagulable state secondary to aPL is the most common mechanism[193]. Other diseaseassociated risk factors and predisposing conditions have been reported, e.g. hypertension, glucocorticoid treatment, hyperhomocysteinaemia, decreased protein S concentration and changes in fibrinolysis [194-196].

A summary of the main mechanisms involved in the pathogenesis of thrombosis in SLE patients can be found in figure 5 .

7.2. Epidemiology and traditional thrombosis risk factors in SLE.

The age at onset of thrombosis in SLE patients is lower than in the general population and its incidence is increased in the first year after diagnosis. This might 
be related to higher SLE activity during this period, higher levels of circulating autoantibodies and immune complexes [197]. Moreover, when focusing on cardiovascular thrombotic events, older age at the time of diagnosis and longer duration of disease also increase risk for thrombosis $[198,199]$. This might be explained by the fact that older SLE patients tend to have more accumulated damage and more vascular morbidity.

The role of ethnicity has also been studied. A large prospective study was undertaken to determine the incidence and risk factors for arterial and venous thromboembolic events in different ethnicity populations [191]. In this study, 625 patients who fulfilled the ACR criteria for SLE were enrolled (258 Chinese, 140 African Americans, and 227 Caucasians). The cumulative hazard of arterial events at 60 months after the diagnosis of SLE was lower in the Caucasians compared to the Chinese and African Americans. There was a significantly lower risk of venous thrombosis events in the Chinese group when compared with Caucasians. These differences could not be fully explained by differences in the prevalence of wellknown risk factors (including age, smoking, diabetes mellitus and hypertension). Genetic and immunologic factors may also play a role [191].

Smoking is a significant risk factor for vascular events in SLE and has been associated with worse outcomes in SLE patients $[198,200]$. Hypertension, diabetes mellitus, and dyslipidaemia are common in SLE patients and these factors have been associated with thrombosis in numerous studies [195, 201]. Given that SLE patients have a greater risk of thrombosis than general population, traditional risk factors should be assessed regularly and treated appropriately.

Glucocorticoids, which are commonly used for SLE treatment, are associated with thrombosis risk and have also been associated with abnormalities in the coagulation cascade when administered in higher doses [202, 203].

7.3. SLE, antiphospholipid antibodies and antiphospholipid syndrome.

$\mathrm{aPL}$ are associated with several clinical features notably venous and arterial thrombosis, thrombocytopaenia and pregnancy loss. However, aPL may only be transiently positive. To be considered significant, they should be persistently positive on two occasions, at least 12 weeks apart.

ACA, lupus anticoagulant and anti-ß2-glycoprotein I (B2GPI) are well-known risk factors for cardiovascular mortality in SLE and are strongly associated with an increased incidence of thrombotic events in these patients [204, 205]. For example, the presence of lupus anticoagulant has been described as a significant risk factor for myocardial infarction [206] and stroke [207]. APS is defined as the presence of at least one clinical criteria (vascular thrombosis or pregnancy morbidity) and one laboratory criteria (lupus anticoagulant, ACA, anti- $\beta 2$ GPI antibodies) [208]. When controlling for other explanatory variables, aPL-positive SLE patients were found to have more than three times the odds of having a thrombotic event compared with those lacking aPL antibodies [204]. Love et al found that among SLE patients, $42 \%$ of the lupus anticoagulant-positive and $40 \%$ of the aPL-positive patients had a history of thrombosis. In contrast, the prevalence of thrombosis in lupus anticoagulant or 
ACA negative SLE patients was only 10-18\% [190]. Other antibodies to negativecharged phospholipids (such as phosphatidic acid, phosphatidylinositol and phosphatidylserine) have been identified but it remains doubtful whether these are actually predictive of thrombosis in SLE patients [209].

The mechanism by which aPL increase the risk of venous and arterial thrombosis is not well understood and several hypothesis have been proposed e.g. they might contribute to increased thrombosis by various possible haemostatic mechanisms such as: clot formation, inhibition of natural anticoagulant mechanisms and impairment of fibrinolysis [210-216].

Although they are called anti-phospholipid antibodies, the most important antigen identified is the protein co-factor $\beta 2 \mathrm{GPI}[217,218]$, aPL can also interact with other phospholipid-binding proteins, particularly with prothrombin [216]. This interaction may disturb endothelial cell function [219]. Moreover, antiprothrombin antibodies have been suggested to possess prothrombinase activity leading to increased fibrin production [217].

aPL react with phospholipid-binding proteins (in particular $\beta 2 \mathrm{GPI}$ and prothrombin) expressed on cell membranes of different cell types, such as monocytes, endothelial cells and platelets. The complex binding between aPL and the corresponding cell membrane protein leads to cell activation by disturbing the cell membrane and promoting signals to the nucleus. Platelet activation (by the anti- $\beta 2 \mathrm{GPI}$ complex) increases the synthesis of thromboxane and the expression of platelet-membrane glycoproteins, such as GPIIb/IIla, which promotes platelet aggregation. Both activated monocytes and endothelial cells upregulate the production of tissue factor and promote endothelial leukocyte adhesion, cytokine secretion and prostaglandin E2 (PGE 2) synthesis [210, 212, 213].

aPL might also induce complement activation, which generates split products that then attract inflammatory cells and initiate thrombosis and tissue injury [220, 221]. Increased complement deposition (C1q, C3d and C4d) on platelets has also been described in SLE, especially in patients with a previous history of venous thrombosis [222, 223]. They also disrupt the fluid phase of coagulation by affecting Protein $\mathrm{C}$ cleavage system (see Protein $\mathrm{C}$ and $\mathrm{S}$ section), by disturbing fibrinolysis (see Fibrinolysis section) and displacing the binding of the natural anticoagulant annexin $A 5$ to anionic structures.

7.4. Impaired fibrinolysis.

Impaired fibrinolysis has been reported in patients with SLE and APS. It contributes to hypercoagulability and an increased risk of thrombosis. Different mechanisms have been described as aetiological agents of impaired fibrinolysis in SLE and APS patients. Some are not related to $\mathrm{aPL}$, such as the increased plasminogen activator inhibitor type 1 (PAl-1) activity that may inhibit tissue plasminogen activator (tPA) activity, while others are related to aPL such $\beta_{2} \mathrm{GPI}$ antibodies, which interferes with the interaction of $\beta_{2} \mathrm{GPI}$ with TPA activator and the enhancement of tPA activity [224].

7.5. Proteins S and C. 
The protein $\mathrm{C}$ system is one of the most important anti-thrombotic pathways mediated by the vessel wall. Activated protein C (APC) inhibits thrombin generation by cleaving procoagulant protein factors $\mathrm{Va}$ and $\mathrm{VIII}$, in the presence of protein $\mathrm{S}$ [225]. Protein $S$ exists in plasma either bound to $C 4 b$-binding protein or as a free form - the latter being the necessary cofactor for activating Protein C. In SLE there is a reduction of free protein $\mathrm{S}$, despite normal total protein $\mathrm{S}$ levels. This may be due to increased $\mathrm{C} 4 \mathrm{~b}$-binding protein or an increased binding affinity between it and protein S [226]. Moreover, aPL may lead to protein C dysfunction by binding to it via its $\beta_{2} \mathrm{GPI}$ antigens [227].

\subsection{Prevention and treatment of thrombosis in SLE patients}

\subsubsection{Prevention treatment.}

The use of low dose aspirin as primary thromboprophylaxis has had conflicting results. Tektonidou et al reported that treatment duration with aspirin and $\mathrm{HCQ}$ is associated with decreased thrombosis in aPL-positive patients [228]. Another study also reported a lower incidence of thrombosis in APLA-positive patients when given ASA prophylaxis [229]. Nevertheless, the Antiphospholipid Antibody Acetylsalicylic Acid (APLASA) study found that low dose aspirin was not effective in preventing thrombosis in positive aPL patients, when compared to placebo [230]. However, this study excluded high-risk groups and has been criticized for being underpowered to detect a beneficial effect of aspirin. However, low-dose aspirin is still used as primary thromboprophylaxis in patients with SLE and persistently positive aPL antibodies [231].

HCQ reduces SLE-related morbidity and mortality and it may also reduce thrombotic risk [195, 204]. Its antithrombotic potential could be explained by multiple mechanisms including: inhibition of platelet aggregation and adhesion [232], inhibition of arachidonic acid release from stimulated platelets [233], cholesterollowering [232], blockade of aPL production [234] and inhibition of the antiphospholipid-induced receptor (GPIIb/IIla) expression [235]. Moreover, HCQ might decrease thrombus size and time of development in a dose-dependent manner [236]. It should be considered in SLE patients who are also positive for aPL, in addition to aspirin.

\subsubsection{Thrombosis treatment}

The risk of recurrent thrombosis in positive aPL patients is between $22 \%$ and $69 \%$ [237-239] and this risk increases in the first year after the discontinuation of anticoagulation treatment $[240,241]$. The duration of tfreatment length depends on the presence of aPL, the site of the thrombosis, recurrence and co-existing precipitating factors. Prolonged anticoagulation therapy may be necessary.

Life-long anticoagulation is recommended in APS patients after a thrombotic event. This recommendation applies to patients with persistently positive moderate to high titres of aPL or with lupus anticoagulant and a definite diagnosis of APS. The target international normalized ratio (INR) for APS syndrome patients is 2-3 for venous events [242, 243] and 3-4 for arterial or recurrent venous events [244]. Patients with thrombosis and aPL positivity who do not fulfil the APS criteria should be managed 
as the general population. Therefore, patients with venous thromboembolism or stroke and a single positive aPL test should be treated with warfarin at a target INR of 2.0-3.0 and low-dose aspirin[245].

The majority of recurrences occur when INR is sub-therapeutic. Hence INR values should be monitored regularly. Moreover, patients with positive lupus anticoagulant can have a spurious increase in INR result, which leads to underdosing of vitamin $\mathrm{K}$ antagonists. If a recurrent event occurred while INR was in therapeutic levels, increasing the target INR to higher than 3.0 should be considered, as well as adding aspirin or switching to low-molecular-weight heparin (LMWH) [241, 246, 247]. The use of direct anticoagulants, namely Rivaroxaban and Apixaban, in patients with APS was successful in some case reports [248] but there were also other unsuccessful reports with Rivaroxaban [249]. A prospective, randomized controlled phase II/III clinical trial of Rivaroxaban in patients with APS (RAPS trial) and previous VTE, with or without systemic lupus erythematosus (SLE) has just been completed. It has sought to determine whether the intensity of anticoagulation achieved with rivaroxaban is not inferior to that of warfarin in these patients [250]. The results indicate that Rivaroxaban is not inferior to warfarin [251]. Recently, other designs of randomised clinical trials with Apixaban (ASTRO-APS) [252] and Rivaroxaban (TRAPS trial) [253] in APS have also been published.

RTX lead to a significant reduction in aPL among SLE patients [254]. Moreover, a high response rate in refractory APS has been described in various case reports and series. The clinical resolution of thrombosis and haematologic manifestations was reported in the majority of these patients and aPL antibodies levels became negative or were significantly reduced $[255,256]$.

\section{Conclusion}

Haematological disorders in SLE patients are very diverse and their pathogenesis is still not fully understood. They can be a manifestation of SLE itself, a concomitant disease or secondary to SLE therapies. The clinical presentation ranges from mild to life-threatening. In the mildest presentations, specific targeted treatment is usually unnecessary, but, in the most severe cases, immunosuppressive therapy with multiple drugs might be lifesaving. However, most evidence is based on case-reports or small retrospective studies, with very few randomized controlled trials reported.

The development of biological therapy in the past 15 years has opened new possible ways to treat the most severe cases more effectively but, as in the other immunosuppressive drugs, more randomized prospective studies and longer followup periods are necessary to establish their optimal role in treating these manifestations. 
TABLES

\section{Red cell alterations in SLE patients}

\section{Main causes of anaemia}

- Chronic disease anaemia.

- Iron deficiency anaemia.

- Blood loss (GI, menorrhagia).

- Nutritional deficiencies of iron

- Autoimmune haemolytic anaemia.

- Microangiopathic haemolitic anaemia.

- Pure red cell aplasia (hypoplastic anaemia).

- Other causes of anaemia:

- Other nutritional deficiencies (vitamin B12, folate).

- Other concomitant immune disorders (pernicious anaemia).

- latrogenic: AZA, CYC.

- Anaemia in pancytopaenia related disorders: Myelofibrosis, thrombotic thrombocytopenic purpura...

Table 1. Red cell alterations in Systemic lupus erythematosus patients.

AZA: azathioprine, CYC: cyclophosphamide, GI: gastrointestinal, SLE: systemic lupus erythematosus. 
Treatment of Autoimmune Haemolytic Anaemia

\begin{tabular}{|c|c|c|c|}
\hline Treatment & Indications & Comments & Ref \\
\hline GCs & $\begin{array}{l}\text { First line therapy. } \\
\text { Initial dose: } 1 \mathrm{mg} / \mathrm{kg} / \text { day. }\end{array}$ & $\begin{array}{l}\text { Refractory: } \\
\text { - After } 3 \text { weeks of treatment } \underline{\text { OR }} \\
\text { - Prednisone }>15 \mathrm{mg} / \text { day } \underline{\text { OR }} \\
\text { - }>0.1 \mathrm{mg} / \mathrm{kg} / \text { day of prednisone equivalent for } \\
\text { maintenance. }\end{array}$ & [31] \\
\hline AZA & \multirow{2}{*}{$\begin{array}{l}\text { To induce remission. } \\
\text { Steroid-sparing agent. }\end{array}$} & \multirow[t]{2}{*}{ Limited evidence in AIHA. } & [31] \\
\hline MMF & & & [257] \\
\hline CSA & $\begin{array}{l}\text { To induce remission in refractory } \\
\text { cases. } \\
\text { Discontinuation may be difficult. }\end{array}$ & $\begin{array}{l}\text { Evidence in refractory AIHA, immune } \\
\text { thrombocytopaenia and Evans syndrome. }\end{array}$ & {$[258]$} \\
\hline CYC & $\begin{array}{l}\text { To induce remission in refractory } \\
\text { cases. }\end{array}$ & $\begin{array}{l}\text { In a study of high-dose treatment of CYC in AIHA } \\
\text { refractory patients: } \\
\text { - All became transfusion independent. } \\
\text { - } 2 / 3 \text { patients went into complete remission (5 } \\
\text { P-AIHA and } 1 \text { S-AIHA). }\end{array}$ & {$[259]$} \\
\hline \multirow[t]{3}{*}{ Splenectomy } & \multirow[t]{3}{*}{$\begin{array}{l}\text { Controversial results. } \\
\text { Cautious use in DAT-positive AIHA. }\end{array}$} & $\begin{array}{l}\text { Out of } 28 \text { patients with AIHA ( } 21 \text { I-AIHA and } 7 \text { S- } \\
\text { AlHA). } \\
\text { - } 2 \text { of S-AlHA had a positive response. } \\
\text { - No criteria to predict response. }\end{array}$ & [260] \\
\hline & & $\begin{array}{l}30 \text { SLE patients with TTP or AIHA. } \\
\text { - No difference between splenectomised and } \\
\text { non-splenectomised. }\end{array}$ & {$[261]$} \\
\hline & & $\begin{array}{l}30 \text { AlHA patients who underwent splenectomy: } \\
\text { - I-AlHA: effective and safe in refractory } \\
\text { patients. } \\
\text { - S-AIHA: increased response to medical } \\
\text { therapy. }\end{array}$ & [262] \\
\hline IVIg & $\begin{array}{l}\text { Possible adjunctive treatment when } \\
\text { significant toxicity to other drugs. }\end{array}$ & $\begin{array}{l}\text { Acute benefit in } 1 / 3 \text { AlHA patients. } \\
\text { Related to good response: } \\
\text { - Hepatomegaly. } \\
\text { - Low pre-treatment } \mathrm{Hb}(6-7 \mathrm{~g} / \mathrm{dl}) \text {. }\end{array}$ & {$[263]$} \\
\hline Danazol & $\begin{array}{l}\text { Sporadic use as an addition to first } \\
\text { line therapy. }\end{array}$ & $\begin{array}{l}17 \text { patients (10 with warm antibody AIHA, } 5 \text { who } \\
\text { relapsed after initial response to prednisone and } \\
2 \text { with refractory AIHA): } \\
\text { - Better responses. } \\
\text { - Unsuccessful in the relapse group. }\end{array}$ & [264] \\
\hline $\begin{array}{l}\text { Plasma } \\
\text { exchange }\end{array}$ & $\begin{array}{l}\text { Use before transfusion of RBC } \\
\text { without benefits. }\end{array}$ & $\begin{array}{l}9 \text { patients and total } 38 \text { sessions of plasma } \\
\text { exchange: } \\
\text { - No significant increase in } \mathrm{Hb} \text { in patients who } \\
\text { underwent plasma-exchange before } \\
\text { transfusion of RBC. }\end{array}$ & [265] \\
\hline RTX & $\begin{array}{l}\text { To induce remission in refractory } \\
\text { cases. }\end{array}$ & $\begin{array}{l}15 \text { children ( } 9 \text { with AIHA and } 6 \text { with Evans } \\
\text { syndrome). } \\
\text { - } 13 \text { patients had }>1.5 \mathrm{~g} / \mathrm{dL} \text { increase of } \mathrm{Hb} \text { and } \\
>50 \% \text { reduction in reticulocyte count. }\end{array}$ & [266] \\
\hline
\end{tabular}




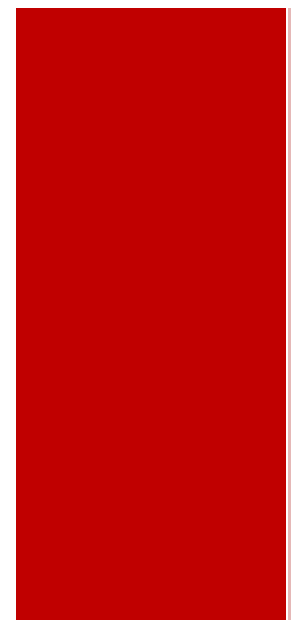

\begin{tabular}{|c|c|}
\hline $\begin{array}{l}\text { - } 2 \text { non-responder patients had AlHA with } \\
\text { warm-reactive IgG autoantibodies. } \\
\text { - DAT positive in } 14 \text { children at pre-treatment } \\
\text { but became negative in } 6 \text { after } 2 \text { months of } \\
\text { treatment. }\end{array}$ & \\
\hline Other reports in paediatric population. & $\begin{array}{l}{[267]} \\
{[268]}\end{array}$ \\
\hline Reports in adult population. & $\begin{array}{l}{[269]} \\
{[270]}\end{array}$ \\
\hline $\begin{array}{l}\text { Phase III RCT: } \\
\text { - Prednisolone and RTX: response increased } \\
\text { gradually over } 6 \text { months. }\end{array}$ & [271] \\
\hline
\end{tabular}

\section{Table 2. Treatment of Autoimmune Haemolytic Anaemia}

AIHA: autoimmune haemolytic anaemia, AZA: azathioprine, CSA: Cyclosporine, CYC: Cyclophosphamide, DAT: direct antiglobulin test, GCs: Glucocorticoids, Hb: haemoglobin, I-AlHA: idiopathic autoimmune haemolytic anaemia, IVIg: Intravenous Immunoglobulin, MMF: Mycophenolate mofetil, RBC: red blood cells, RCT: randomized clinical trial, RTX: Rituximab, Ref: references, S-AIHA: Secondary autoimmune haemolytic anaemia, TTP: Thrombotic thrombocytopaenic purpura.

\section{White cell alterations in SLE patients}

\section{Main causes of leukopaenia}

- Neutropaenia.

- Immune mediated.

- Infections.

- latrogenic (AZA, CYC).

- Lymphopaenia.

- Immune mediated.

- Infection (viral).

- latrogenic.

- Infections.

\section{Main causes of leukocytosis}

- Disease activity.

- latrogenic: use of GC.

Table 3. White cell alterations in Systemic lupus erythematosus patients.

AZA: azathioprine, CYC: cyclophosphamide, GC: glucocorticoids, GI: gastrointestinal, SLE: systemic lupus erythematosus. 


\section{Platelet alterations in SLE patients}

\section{Main causes of thrombocytopaenia}

- Immune mediated thrombocytopaenia.

- Infections.

- latrogenic (AZA, CYC).

- Antiphospholipid syndrome.

- Anaemia in bi/pancytopaenia related disorders: Thrombotic thrombocytopenic purpura, myelofibrosis...

- Pseudothrombocytopaenia.

\section{Main causes of thrombocytosis}

- Infections.

- Disease activity.

- Hyposplenism

Table 4. Platelet alterations in Systemic lupus erythematosus patients.

AZA: azathioprine, CYC: cyclophosphamide, GI: gastrointestinal, SLE: systemic lupus erythematosus.

\section{SLE IMMUNE TRHOMBOCYTOPAENIA PRESENTATION}
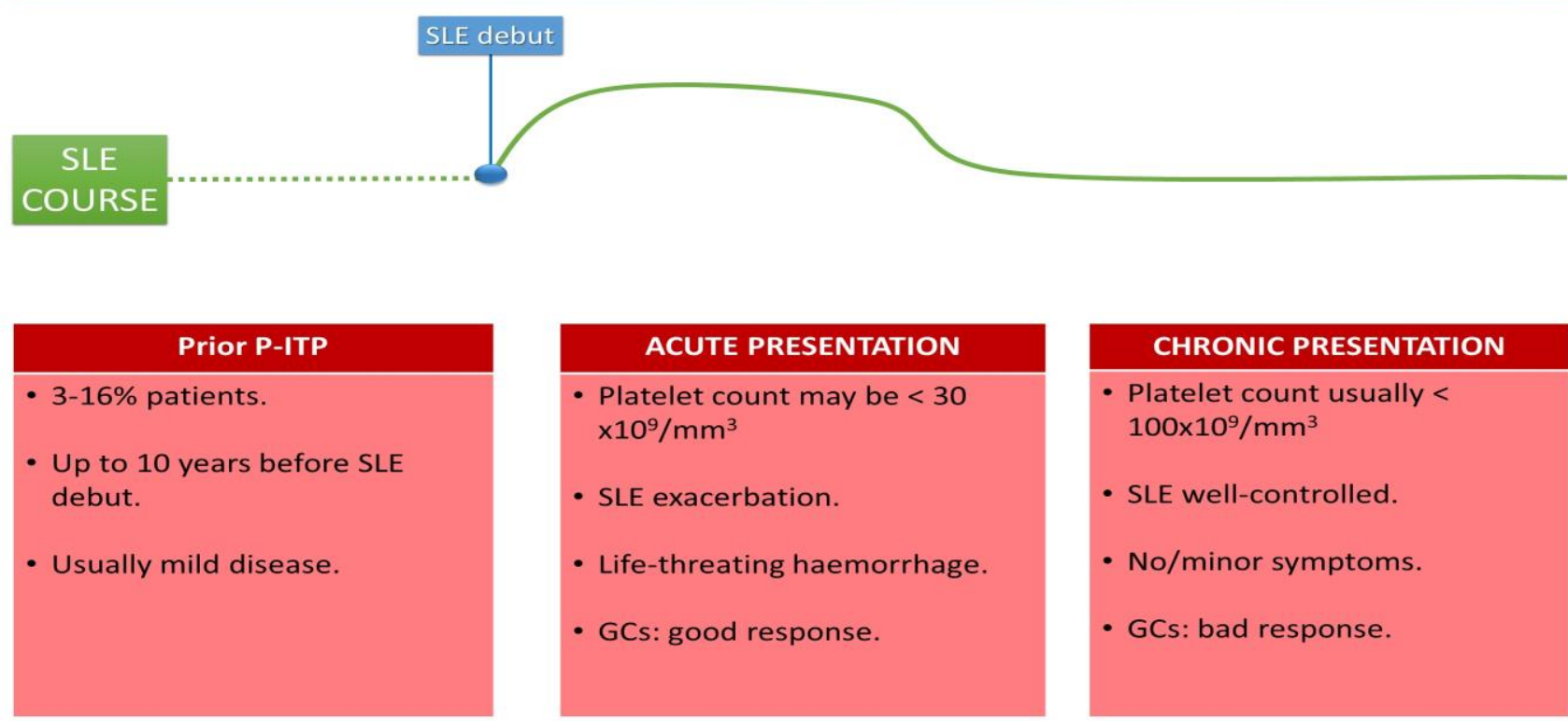

\section{CHRONIC PRESENTATION}

- Platelet count usually < $100 \times 10^{9} / \mathrm{mm}^{3}$

- SLE well-controlled.

- No/minor symptoms.

- GCs: bad response.

Table 5. Systemic lupus erythematosus immune thrombocytopaenia presentation.

GCs: glucocorticoids, P-ITP: primary immune thrombocytopaenia, SLE: systemic lupus erythematosus. 
Treatment of Immune Thrombocytopaenia

\begin{tabular}{|c|c|c|c|}
\hline Treatment & Indications & Comments & Ref \\
\hline GCs & First line therapy. & $\begin{array}{l}\text { - Response within 1-8 weeks. } \\
\text { - High rate of long-term failure. } \\
\text { Oral high-dose dexamethasone } \\
\text { (40mg/day for } 4 \text { days } x 4-8 \text { cycles } \\
\text { with intervals of } 2-4 \text { weeks). } \\
\text { Prednisone (tapering from 0,5- } \\
\text { 1mg/kg/day) can be used, but } \\
\text { dexamethasone has similar } \\
\text { remission rates and better long-term } \\
\text { responses. } \\
\text { Pulse methylprednisolone has an } \\
\text { increased risk of serious adverse } \\
\text { effects (mainly avascular necrosis) } \\
\text { without added benefits when } \\
\text { compared to high-dose oral GCs. }\end{array}$ & $\begin{array}{l}{[114]} \\
{[115]} \\
{[116]}\end{array}$ \\
\hline \multirow{4}{*}{ Danazol } & \multirow{4}{*}{$\begin{array}{l}\text { In combination with GCs when refractory } \\
\text { to first line therapy. }\end{array}$} & Variable dosing between studies. & $\begin{array}{l}{[116]} \\
{[272]} \\
{[273]}\end{array}$ \\
\hline & & $\begin{array}{l}16 \text { patients: } \\
\text { - Initially treated with } 200 \mathrm{mg} / \text { day } \\
\text { and then increased by } 200 \mathrm{mg} \\
\text { every four weeks until response. } \\
\text { - All patients had a good response } \\
\text { within two months. } \\
\text { - In an average follow-up of } 18.2 \\
\text { months, danazol was tapered } \\
\text { down to } 200 / 400 \mathrm{mg} / \text { day } \\
\text { without recurrence. }\end{array}$ & [185] \\
\hline & & $\begin{array}{l}6 \text { patients refractory to GCs were } \\
\text { successfully treated with: } \\
\text { - High initial dose ( } 800 \mathrm{mg} / \text { day for } \\
8 \text { weeks). } \\
\text { - Lower maintenance dose } \\
\text { (ranging from } 200 \text { to } 600 \\
\text { mg/day). } \\
\text { Danazol could not be discontinued } \\
\text { without recurrence. }\end{array}$ & {$[274]$} \\
\hline & & $\begin{array}{l}\text { - Danazol is safe and well } \\
\text { tolerated. } \\
\text { - It may be used during pregnancy. }\end{array}$ & {$[275]$} \\
\hline
\end{tabular}




\begin{tabular}{|c|c|c|c|}
\hline HCQ & & $\begin{array}{l}\text { - Increased rate of sustained } \\
\text { response. }\end{array}$ & [116] \\
\hline \multirow{2}{*}{ CYC } & \multirow{2}{*}{ Refractory immune thrombocytopaenia. } & $\begin{array}{l}\text { 10-15 mg/kg intravenous CYC, } \\
\text { monthly for at least } 4 \text { months: } \\
\text { - Platelet count increases within 2- } \\
18 \text { weeks. } \\
\text { - High rates of sustained response. } \\
\text { - Maintenance therapy rarely } \\
\text { needed }\end{array}$ & [276] \\
\hline & & $\begin{array}{l}\text { Concerns about adverse effects led } \\
\text { to the proposal of new regimen: } \\
\text { - Induction dose } 500 \mathrm{mg} \text {, biweekly } \\
\text { for } 3 \text { months. } \\
\text { - Followed by MMF or AZA, } \\
\text { improving tolerability without } \\
\text { loss of efficacy. }\end{array}$ & [277] \\
\hline MMF & $\begin{array}{l}\text { Refractory immune thrombocytopaenia. } \\
\text { Steroid-sparing agent. }\end{array}$ & $\begin{array}{l}\text { Case report of its use as } \\
\text { maintenance therapy [277]. }\end{array}$ & $\begin{array}{l}{[278]} \\
{[279]} \\
{[280]}\end{array}$ \\
\hline AZA & Steroid-sparing agent. & $\begin{array}{l}\text { Case report of its use as } \\
\text { maintenance therapy [277]. }\end{array}$ & $\begin{array}{l}{[281]} \\
{[282]}\end{array}$ \\
\hline CSA & \multirow{2}{*}{$\begin{array}{l}\text { Refractory immune thrombocytopaenia. } \\
\text { Steroid-sparing agent. }\end{array}$} & $\begin{array}{l}\text { - Risk of nephrotoxicity } \\
\text { - Lower doses have been } \\
\text { successfully used. }\end{array}$ & $\begin{array}{l}{[283]} \\
{[284]} \\
{[285]}\end{array}$ \\
\hline Vincristine & & $\begin{array}{l}\text { - Severe side effects: neuropathy } \\
\text { and bone pain. }\end{array}$ & [286] \\
\hline IVlg & $\begin{array}{l}\text { Preferred if rapid rise in platelet count is } \\
\text { necessary due to: } \\
\text { - Active bleeding. } \\
\text { - Emergent surgery. }\end{array}$ & $\begin{array}{l}\text { Initial dose: } 400 \mathrm{mg} / \mathrm{kg} \text { daily for } 5 \\
\text { consecutive days. } \\
\text { Maintenance: } 400 \mathrm{mg} / \mathrm{kg} \text { monthly in } \\
\text { an } \\
\text { intermittent or continuous manner. } \\
\text { Not enough evidence analysing long- } \\
\text { lasting response. }\end{array}$ & $\begin{array}{l}{[287]} \\
{[288]} \\
{[289]} \\
{[290]} \\
{[291]} \\
{[292]}\end{array}$ \\
\hline \multirow{3}{*}{ Splenectomy } & \multirow{3}{*}{ Refractory immune thrombocytopaenia. } & $\begin{array}{l}\text { Good short term response in SLE } \\
\text { patients. }\end{array}$ & $\begin{array}{l}{[117,} \\
293] \\
{[118]} \\
{[294]}\end{array}$ \\
\hline & & \multicolumn{2}{|c|}{$\begin{array}{l}\text { Controversial results in long-term response } \\
\text { when compared with P-ITP. } \\
\text { Lack of follow-up in studies }\end{array}$} \\
\hline & & Less durable response. & [119] \\
\hline
\end{tabular}




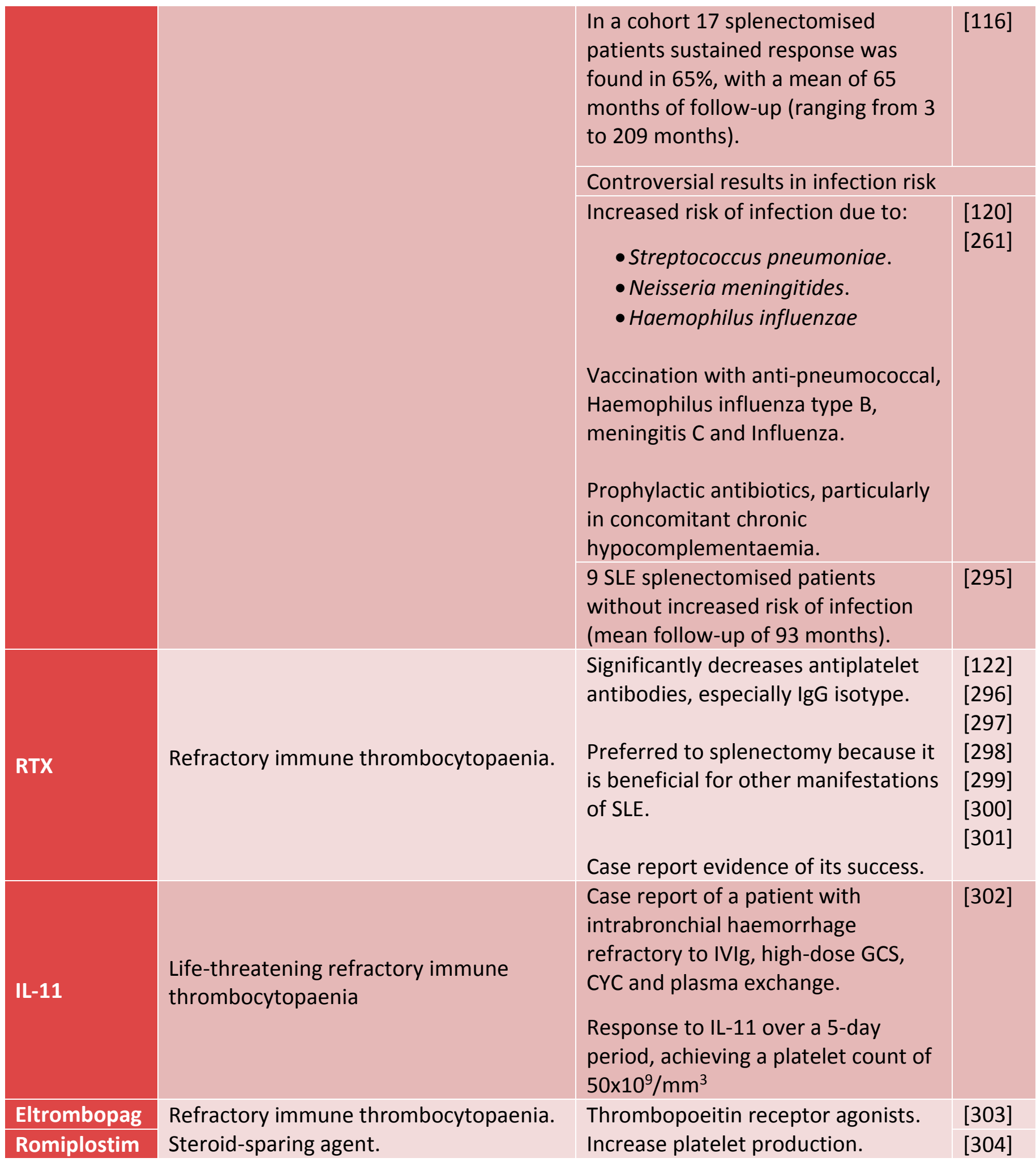

Table 6. Treatment of Immune Thrombocytopaenia.

AZA: azathioprine, CSA: Cyclosporine, CYC: Cyclophosphamide, GCs: Glucocorticoids, HCQ: Hydroxychloroquine, IVIg: Intravenous immunoglobulin, SLE: Systemic lupus erythematosus. 


\section{FIGURES}

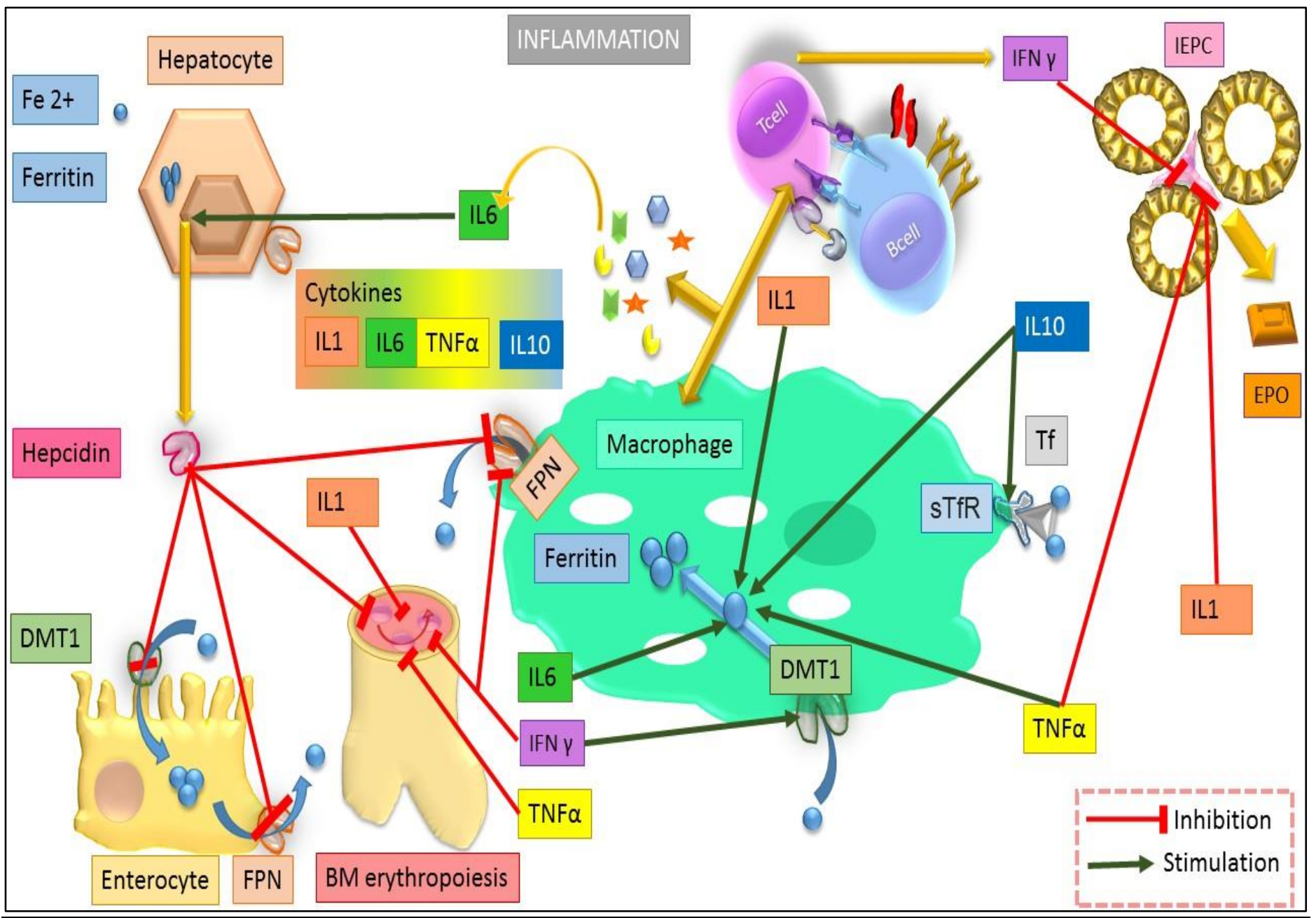

Figure 1 Chronic disease anaemia pathogenesis.

Righ corner: Hepcidin role in chronic disease anaemia.Left corner: Cytokin role in chronic disease anaemia. Red lines indicate inhibition and green lines indicate stimulation.

BM: bone marrow, DMT1: divalent metal transporter 1, EPO: erythropoietin, Fe 2+: iron, FPN: ferroportin, IEPC: intersticial epo producting cells, IFN $\gamma$ : interferon $\gamma$, IL1: interleukin 1, IL6: interleukin 6, IL10: interleukin 10, Tf: transferrin, TNF $\alpha$ : tumour necrosis factor $\alpha$, sTfR: soluble transferrin receptor. 


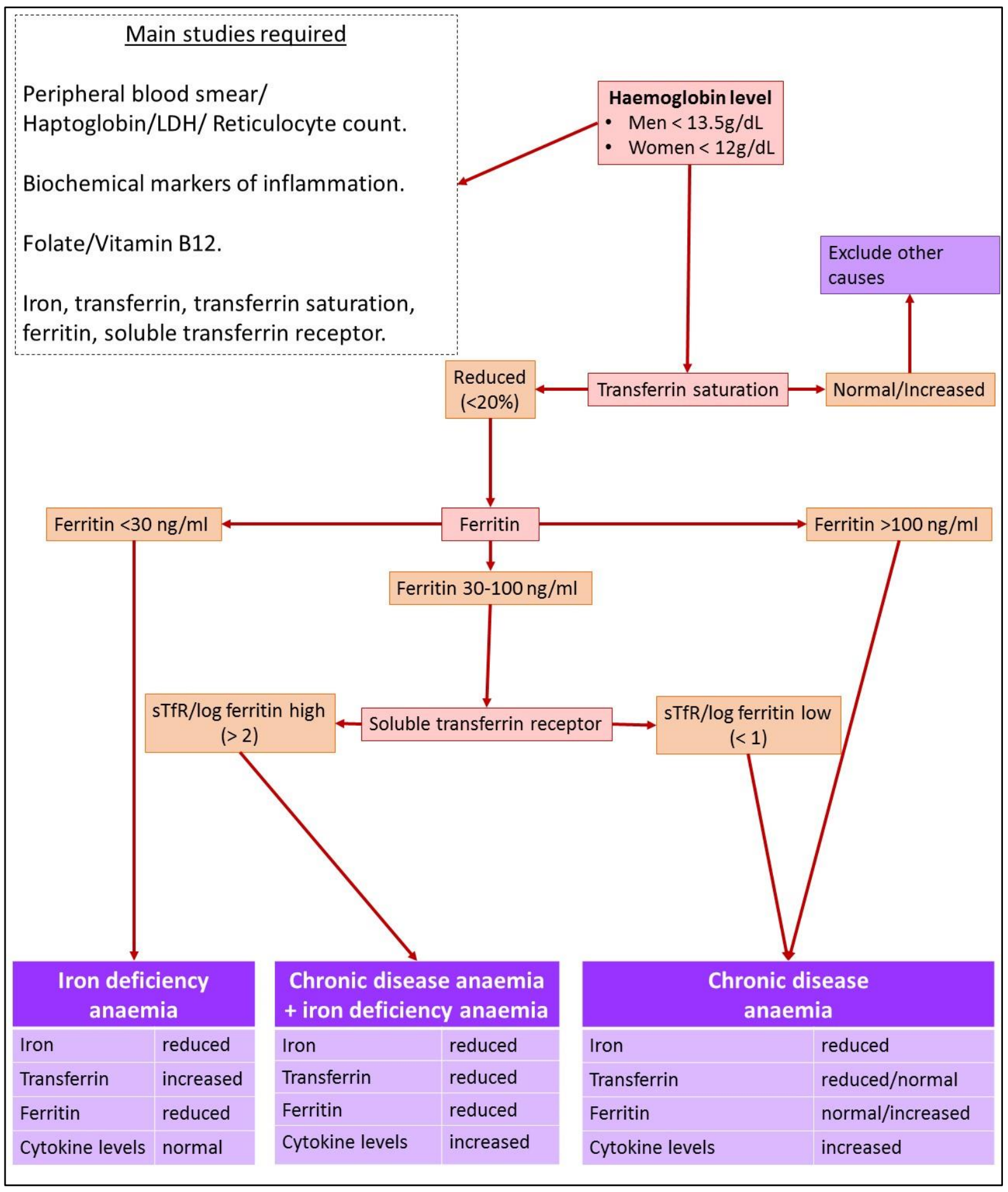

Figure 2. Differential diagnose of systemic lupus erythematosus anaemias: iron deficiency anaemia and chronic disease anaemia.

sTfR: soluble transferrin receptor. 


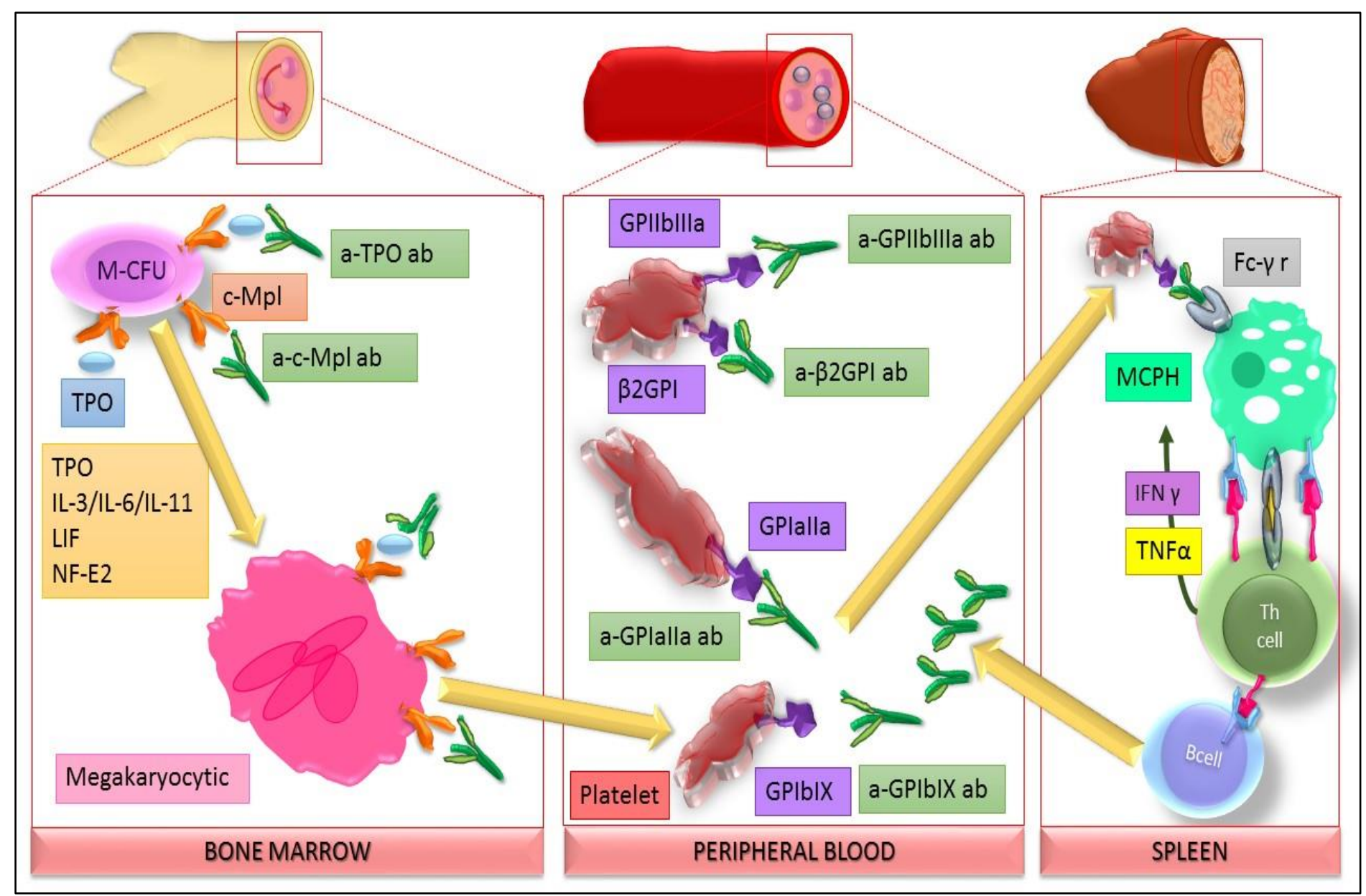

Figure 3. Systemic lupus erythematosus immune thrombocytopaenia pathogenesis. A summary of autoantibodies interactions in bone marrow, peripheral blood and spleen.

a- B2GPI ab: anti 62 glycoprotein I antibody, a-c-Mpl ab: anti thrombopoietin receptor antibody, a- GPlalla ab: anti glycoprotein lalla antibody, a-GPIbIX ab: anti glycoprotein IbIX antibody, a-GPIIbIlla ab: anti glycoprotein IIbllla antibody, a-TPO ab: anti thrombopoietin antibody, 62GPI: 62 glycoprotein I, c-Mpl: thrombopoietin receptor, Fc- $\gamma$ r: fragment, crystallisable y receptor, GPlalla: glycoprotein lalla, GPIbIX: glycoprotein IbIX, GPIIbIIla: glycoprotein IIbIIla, IFN Y: interferon Y, IL-3: interleukin 3, IL-6: interleukin 6, IL-11: interleukin 11, LIF: leukemia inhibitory factor, M-CFU: Megakaryocytic colony forming units, MCPH: Macrophage, NF-E2: transcription factor NF-E2 45 kDa subunit, TNF $\alpha$ : tumour necrosis factor $\alpha$, TPO: thrombopoietin. 


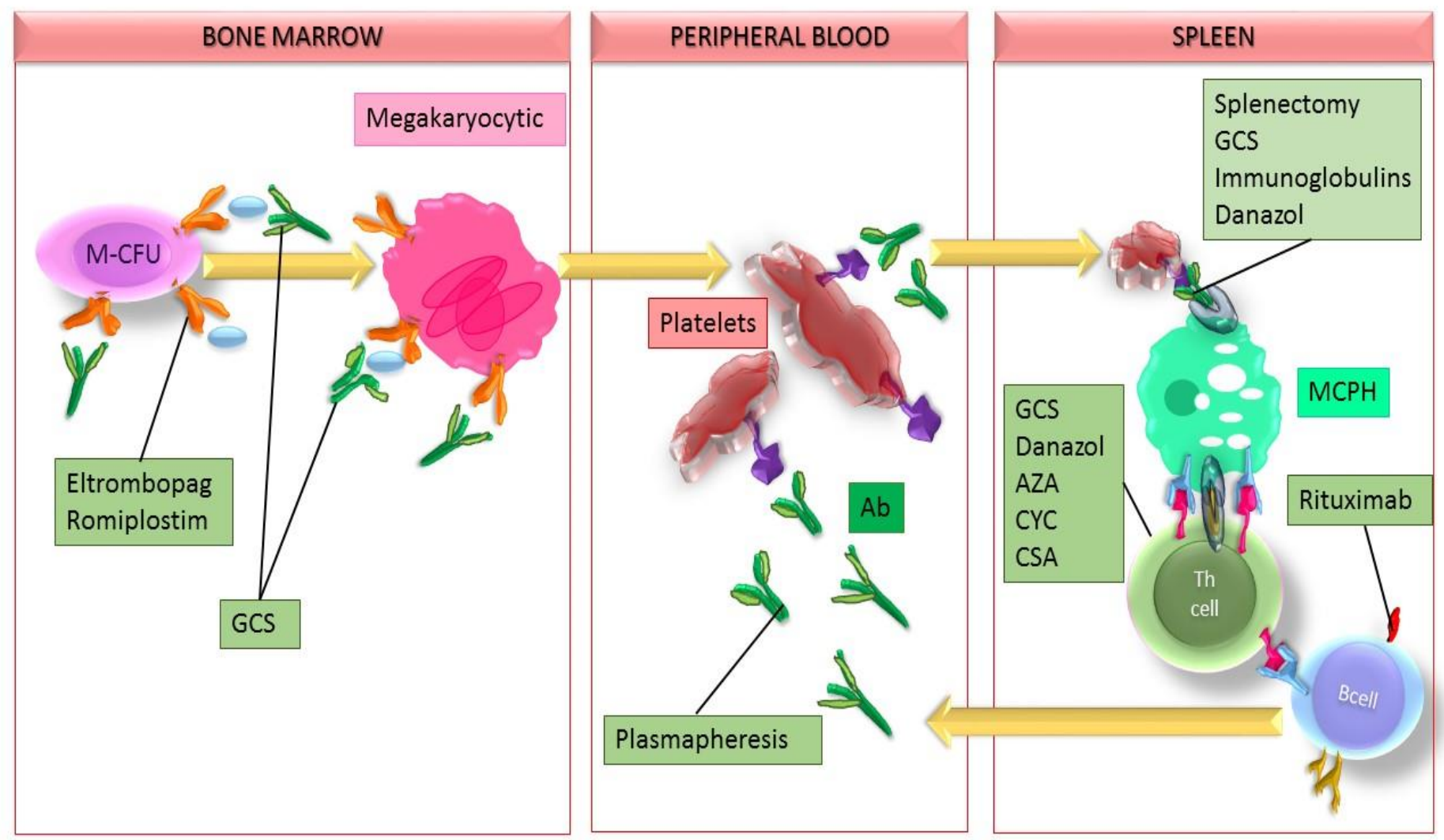

Figure 4. Systemic lupus erythematosus immune thrombocytopaenia: treatments and targets.

Ab: autoantibodies, AZA: azathioprine, CSA: cyclosporine, CYC: cyclosphosphamide, GCS: glucocorticoids, MCFU: Megakaryocytic colony forming units, MCPH: Macrophage. 


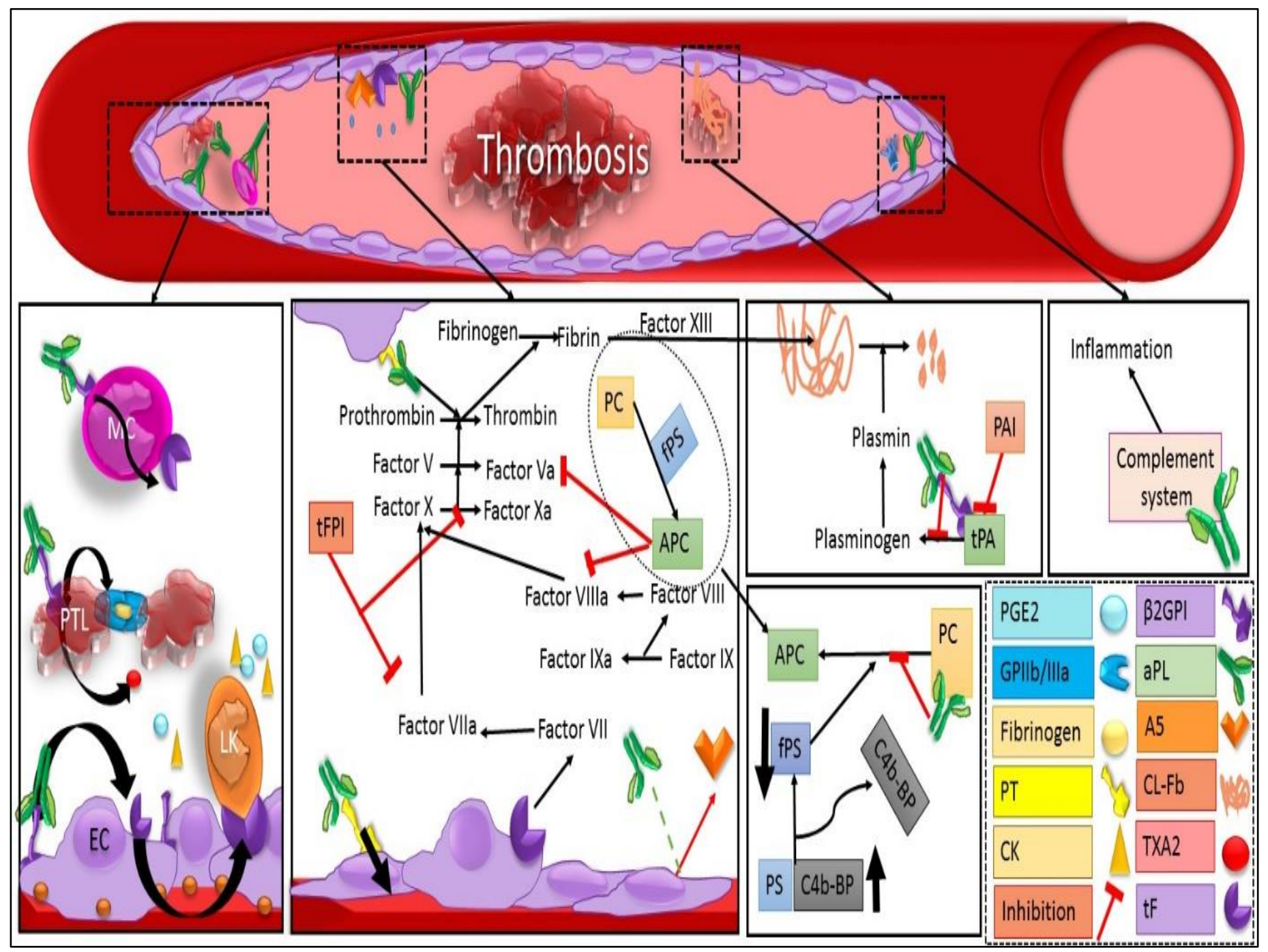

Figure 5. Main mechanisms in the pathogenesis of thrombosis in systemic lupus erythematosus patients.

1. Interaction of antiphospholipid antibodies with cell membranes of monocytes, endothelial cells and platelets.

2. Alterations in the coagulation cascade.

3. Impairment of fibrinolysis and interaction with protein $\mathrm{S}$ and protein $\mathrm{C}$.

4. Complement system role.

A5: annexin A5, APC: activated protein C, aPL: antiphospholipid antibody, 62GPI: 62 glycoprotein I, C4b-BP: C4b-binding protein, CK: cytokines, CL-Fb: cross linked fibrin, EC: endothelial cell, GPIIb/IIla: glycoprotein IIb/IIla, LK: leukocyte, MC: monocyte, PAl: plasminogen activator inhibitor type 1 PC: protein C, PGE2: prostaglandin E2, PS: protein S, PT: prothrombin antigen, tF: tissue factor, tFPI: tissue factor pathway inhibitor, tPA: tissue plasminogen activator, TXA2: Thromboxane A2. 


\section{References}

[1] Alarcón GS, McGwin G, Roseman JM, Uribe A, Fessler BJ, Bastian HM et al. Systemic lupus erythematosus in three ethnic groups. XIX. Natural history of the accrual of the American College of Rheumatology criteria prior to the occurrence of criteria diagnosis. Arthritis Rheum, 2004;51:609-15.

[2] Hochberg MC. Updating the American College of Rheumatology revised criteria for the classification of systemic lupus erythematosus. Arthritis Rheum, 1997;40:1725.

[3] Petri M, Orbai AM, Alarcón GS, Gordon C, Merrill JT, Fortin PR et al. Derivation and validation of the Systemic Lupus International Collaborating Clinics classification criteria for systemic lupus erythematosus. Arthritis Rheum, 2012;64:2677-86.

[4] Budman DR, Steinberg AD. Hematologic aspects of systemic lupus erythematosus. Current concepts. Ann Intern Med, 1977;86:220-9.

[5] Tzioufas AG, Kokori SI, Petrovas Cl, Moutsopoulos HM. Autoantibodies to human recombinant erythropoietin in patients with systemic lupus erythematosus: correlation with anemia. Arthritis Rheum, 1997;40:2212-6.

[6] WHO. Haemoglobin concentrations for the diagnosis of anaemia and assessment of severity. Vitamin and Mineral Nutrition Information System., Geneva: World Health Organization, 2011 (WHO/NMH/NHD/MNM/11.1).

[7] Voulgarelis M, Kokori SI, loannidis JP, Tzioufas AG, Kyriaki D, Moutsopoulos $\mathrm{HM}$. Anaemia in systemic lupus erythematosus: aetiological profile and the role of erythropoietin. Ann Rheum Dis, 2000;59:217-22.

[8] Ganz T, Nemeth E. Hepcidin and iron homeostasis. Biochim Biophys Acta, 2012;1823:1434-43.

[9] Baker JF, Ghio AJ. Iron homoeostasis in rheumatic disease. Rheumatology (Oxford), 2009;48:1339-44.

[10] Nemeth E, Rivera S, Gabayan V, Keller C, Taudorf S, Pedersen BK et al. IL-6 mediates hypoferremia of inflammation by inducing the synthesis of the iron regulatory hormone hepcidin. J Clin Invest, 2004;113:1271-6.

[11] Ripley BJ, Goncalves B, Isenberg DA, Latchman DS, Rahman A. Raised levels of interleukin 6 in systemic lupus erythematosus correlate with anaemia. Ann Rheum Dis, 2005;64:849-53.

[12] Verga Falzacappa MV, Vujic Spasic M, Kessler R, Stolte J, Hentze MW, Muckenthaler MU. STAT3 mediates hepatic hepcidin expression and its inflammatory stimulation. Blood, 2007;109:353-8.

[13] Ludwiczek S, Aigner E, Theurl I, Weiss G. Cytokine-mediated regulation of iron transport in human monocytic cells. Blood, 2003;101:4148-54.

[14] Koca SS, Isik A, Ustundag B, Metin K, Aksoy K. Serum pro-hepcidin levels in rheumatoid arthritis and systemic lupus erythematosus. Inflammation, 2008;31:146-53.

[15] Schett G, Firbas U, Füreder W, Hiesberger H, Winkler S, Wachauer D et al. Decreased serum erythropoietin and its relation to anti-erythropoietin 
antibodies in anaemia of systemic lupus erythematosus. Rheumatology (Oxford), 2001;40:424-31.

[16] Weiss G, Schett G. Anaemia in inflammatory rheumatic diseases. Nat Rev Rheumatol, 2013;9:205-15.

[17] Liu H, Ozaki K, Matsuzaki Y, Abe M, Kosaka M, Saito S. Suppression of haematopoiesis by IgG autoantibodies from patients with systemic lupus erythematosus (SLE). Clin Exp Immunol, 1995;100:480-5.

[18] Weiss G, Goodnough LT. Anemia of chronic disease. N Engl J Med, 2005;352:1011-23.

[19] Levine AB, Erkan D. Clinical assessment and management of cytopenias in lupus patients. Curr Rheumatol Rep, 2011;13:291-9.

[20] Mast AE, Blinder MA, Gronowski AM, Chumley C, Scott MG. Clinical utility of the soluble transferrin receptor and comparison with serum ferritin in several populations. Clin Chem, 1998;44:45-51.

[21] Skikne BS, Punnonen K, Caldron PH, Bennett MT, Rehu M, Gasior GH et al. Improved differential diagnosis of anemia of chronic disease and iron deficiency anemia: a prospective multicenter evaluation of soluble transferrin receptor and the sTfR/log ferritin index. Am J Hematol, 2011;86:923-7.

[22] Weiss G. Iron metabolism in the anemia of chronic disease. Biochim Biophys Acta, 2009;1790:682-93.

[23] Kletzmayr J, Sunder-Plassmann G, Hörl WH. High dose intravenous iron: a note of caution. Nephrol Dial Transplant, 2002;17:962-5.

[24] Newman K, Owlia MB, El-Hemaidi I, Akhtari M. Management of immune cytopenias in patients with systemic lupus erythematosus - Old and new. Autoimmun Rev, 2013;12:784-91.

[25] Kokori SI, Ioannidis JP, Voulgarelis M, Tzioufas AG, Moutsopoulos HM. Autoimmune hemolytic anemia in patients with systemic lupus erythematosus. Am J Med, 2000;108:198-204.

[26] Packman $\mathrm{CH}$. Hemolytic anemia due to warm autoantibodies. Blood Rev, 2008;22:17-31.

[27] Sultan SM, Begum S, Isenberg DA. Prevalence, patterns of disease and outcome in patients with systemic lupus erythematosus who develop severe haematological problems. Rheumatology (Oxford), 2003;42:230-4.

[28] Font J, Cervera R, Ramos-Casals M, García-Carrasco M, Sents J, Herrero C et al. Clusters of clinical and immunologic features in systemic lupus erythematosus: analysis of 600 patients from a single center. Semin Arthritis Rheum, 2004;33:217-30.

[29] Jeffries M, Hamadeh F, Aberle T, Glenn S, Kamen DL, Kelly JA et al. Haemolytic anaemia in a multi-ethnic cohort of lupus patients: a clinical and serological perspective. Lupus, 2008;17:739-43.

[30] Fayyaz A, Igoe A, Kurien BT, Danda D, James JA, Stafford HA et al. Haematological manifestations of lupus. Lupus Sci Med, 2015;2:e000078.

[31] GA K. Hematological and Lymphoid Abnomalities in SLE. In: DJ W, BH H, editors. DUBOIS ' Lupus erythmatosus and Related Syndomes, Philadelphia: Elsevier; 2013, p. $426-37$. 
[32] Lang B, Straub RH, Weber S, Röther E, Fleck M, Peter HH. Elevated anticardiolipin antibodies in autoimmune haemolytic anaemia irrespective of underlying systemic lupus erythematosus. Lupus, 1997;6:652-5.

[33] Fong KY, Loizou S, Boey ML, Walport MJ. Anticardiolipin antibodies, haemolytic anaemia and thrombocytopenia in systemic lupus erythematosus. Br J Rheumatol, 1992;31:453-5.

[34] Arvieux J, Roussel B, Ponard D, Colomb MG. Reactivity patterns of antiphospholipid antibodies in systemic lupus erythematosus sera in relation to erythrocyte binding and complement activation. Clin Exp Immunol, 1991;84:466-71.

[35] Barker RN, de Sá Oliveira GG, Elson CJ, Lydyard PM. Pathogenic autoantibodies in the NZB mouse are specific for erythrocyte band 3 protein. Eur J Immunol, 1993;23:1723-6.

[36] Ruiz-Argüelles A, Llorente L. The role of complement regulatory proteins (CD55 and CD59) in the pathogenesis of autoimmune hemocytopenias. Autoimmun Rev, 2007;6:155-61.

[37] Richaud-Patin Y, Pérez-Romano B, Carrillo-Maravilla E, Rodriguez AB, Simon AJ, Cabiedes J et al. Deficiency of red cell bound CD55 and CD59 in patients with systemic lupus erythematosus. Immunol Lett, 2003;88:95-9.

[38] Domiciano DS, Shinjo SK. Autoimmune hemolytic anemia in systemic lupus erythematosus: association with thrombocytopenia. Clin Rheumatol, 2010;29:1427-31.

[39] Durán S, Apte M, Alarcón GS, Marion MC, Edberg JC, Kimberly RP et al. Features associated with, and the impact of, hemolytic anemia in patients with systemic lupus erythematosus: LX, results from a multiethnic cohort. Arthritis Rheum, 2008;59:1332-40.

[40] Gomard-Mennesson E, Ruivard M, Koenig M, Woods A, Magy N, Ninet J et al. Treatment of isolated severe immune hemolytic anaemia associated with systemic lupus erythematosus: 26 cases. Lupus, 2006;15:223-31.

[41] Barcellini W, Fattizzo B, Zaninoni A, Radice T, Nichele I, Di Bona E et al. Clinical heterogeneity and predictors of outcome in primary autoimmune hemolytic anemia: a GIMEMA study of 308 patients. Blood, 2014;124:2930-6.

[42] Gómez-Almaguer D, Solano-Genesta M, Tarín-Arzaga L, Herrera-Garza JL, Cantú-Rodríguez OG, Gutiérrez-Aguirre $\mathrm{CH}$ et al. Low-dose rituximab and alemtuzumab combination therapy for patients with steroid-refractory autoimmune cytopenias. Blood, 2010;116:4783-5.

[43] Chao MP, Hong J, Kunder C, Lester L, Schrier SL, Majeti R. Refractory warm IgM-mediated autoimmune hemolytic anemia associated with Churg-Strauss syndrome responsive to eculizumab and rituximab. Am J Hematol, 2015;90:78-81.

[44] Wouters D, Stephan F, Strengers P, de Haas M, Brouwer C, Hagenbeek A et al. C1-esterase inhibitor concentrate rescues erythrocytes from complementmediated destruction in autoimmune hemolytic anemia. Blood, 2013;121:1242-4.

[45] SYMMERS WS. Thrombotic microangiopathic haemolytic anaemia (thrombotic microangiopathy). Br Med J, 1952;2:897-903. 
[46] Espinosa G, Bucciarelli S, Cervera R, Lozano M, Reverter JC, de la Red G et al. Thrombotic microangiopathic haemolytic anaemia and antiphospholipid antibodies. Ann Rheum Dis, 2004;63:730-6.

[47] Dold S, Singh R, Sarwar H, Menon Y, Candia L, Espinoza LR. Frequency of microangiopathic hemolytic anemia in patients with systemic lupus erythematosus exacerbation: Distinction from thrombotic thrombocytopenic purpura, prognosis, and outcome. Arthritis Rheum, 2005;53:982-5.

[48] Shah AA, Higgins JP, Chakravarty EF. Thrombotic microangiopathic hemolytic anemia in a patient with SLE: diagnostic difficulties. Nat Clin Pract Rheumatol, 2007;3:357-62.

[49] Fisch P, Handgretinger R, Schaefer HE. Pure red cell aplasia. Br J Haematol, 2000;111:1010-22.

[50] Habib GS, Saliba WR, Froom P. Pure red cell aplasia and lupus. Semin Arthritis Rheum, 2002;31:279-83.

[51] Hara A, Wada T, Kitajima S, Toyama T, Okumura T, Kitagawa K et al. Combined pure red cell aplasia and autoimmune hemolytic anemia in systemic lupus erythematosus with anti-erythropoietin autoantibodies. Am J Hematol, 2008;83:750-2.

[52] Roffe C, Cahill MR, Samanta A, Bricknell S, Durrant ST. Aplastic anaemia in systemic lupus erythematosus: a cellular immune mechanism? $\mathrm{Br} \mathrm{J}$ Rheumatol, 1991;30:301-4.

[53] Singh NP, Prakash A, Garg D, Makhija A, Pathania A, Prakash N et al. Aplastic anemia complicating systemic lupus erythematosus: successful management with cyclosporine. Rheumatol Int, 2004;24:40-2.

[54] Brooks BJ, Broxmeyer HE, Bryan CF, Leech SH. Serum inhibitor in systemic lupus erythematosus associated with aplastic anemia. Arch Intern Med, 1984;144:1474-7.

[55] Tagoe C, Shah A, Yee H, Belmont HM. Aplastic anemia in systemic lupus erythematosus: a distinct presentation of acquired aplastic anemia? J Clin Rheumatol, 2001;7:377-83.

[56] Winkler A, Jackson RW, Kay DS, Mitchell E, Carmignani S, Sharp GC. High-dose intravenous cyclophosphamide treatment of systemic lupus erythematosusassociated aplastic anemia. Arthritis Rheum, 1988;31:693-4.

[57] Segal R, Baumoehl Y, Elkayam O, Levartovsky D, Litinsky I, Paran D et al. Anemia, serum vitamin B12, and folic acid in patients with rheumatoid arthritis, psoriatic arthritis, and systemic lupus erythematosus. Rheumatol Int, 2004;24:14-9.

[58] Juncà J, Cuxart A, Tural C, Marti S. Systemic lupus erythematosus and pernicious anemia in an 82-year-old woman. J Rheumatol, 1991;18:1924-5.

[59] Benjilali L, Tazi-Mezalek Z, Harmouche H, Lebbar K, Aouni M, Adnaoui M et al. Pernicious anemia in a young man with systemic lupus erythematosus. Lupus, 2007;16:827-9.

[60] Singh A. An uncommon cause of anemia in systemic lupus erythematosus. Int J Rheum Dis, 2013;16:783-5.

[61] Tan EM, Cohen AS, Fries JF, Masi AT, McShane DJ, Rothfield NF et al. The 1982 revised criteria for the classification of systemic lupus erythematosus. Arthritis Rheum, 1982;25:1271-7. 
[62] Capsoni F, Sarzi-Puttini P, Zanella A. Primary and secondary autoimmune neutropenia. Arthritis Res Ther, 2005;7:208-14.

[63] Martínez-Baños D, Crispín JC, Lazo-Langner A, Sánchez-Guerrero J. Moderate and severe neutropenia in patients with systemic lupus erythematosus. Rheumatology (Oxford), 2006;45:994-8.

[64] Harmon DC, Weitzman SA, Stossel TP. The severity of immune neutropenia correlates with the maturational specificity of antineutrophil antibodies. $\mathrm{Br} \mathrm{J}$ Haematol, 1984;58:209-15.

[65] Yamasaki K, Niho Y, Yanase T. Granulopoiesis in systemic lupus erythematosus. Arthritis Rheum, 1983;26:516-21.

[66] Hadley AG, Byron MA, Chapel HM, Bunch C, Holburn AM. Anti-granulocyte opsonic activity in sera from patients with systemic lupus erythematosus. $\mathrm{Br} \mathrm{J}$ Haematol, 1987;65:61-5.

[67] Rustagi PK, Currie MS, Logue GL. Complement-activating antineutrophil antibody in systemic lupus erythematosus. Am J Med, 1985;78:971-7.

[68] Kurien BT, Newland J, Paczkowski C, Moore KL, Scofield RH. Association of neutropenia in systemic lupus erythematosus (SLE) with anti-Ro and binding of an immunologically cross-reactive neutrophil membrane antigen. Clin Exp Immunol, 2000;120:209-17.

[69] Kondo H, Date Y, Sakai Y, Akimoto M. Effective simultaneous rhG-CSF and methylprednisolone "pulse" therapy in agranulocytosis associated with systemic lupus erythematosus. Am J Hematol, 1994;46:157-8.

[70] Euler HH, Harten P, Zeuner RA, Schwab UM. Recombinant human granulocyte colony stimulating factor in patients with systemic lupus erythematosus associated neutropenia and refractory infections. J Rheumatol, 1997;24:2153-7.

[71] Rivero SJ, Díaz-Jouanen E, Alarcón-Segovia D. Lymphopenia in systemic lupus erythematosus. Clinical, diagnostic, and prognostic significance. Arthritis Rheum, 1978;21:295-305.

[72] Noguchi M, Iwamori M, Hirano T, Kobayashi S, Hashimoto H, Hirose S et al. Autoantibodies to $T$ and $B$ cell lines detected in serum samples from patients with systemic lupus erythematosus with lymphopenia and hypocomplementaemia. Ann Rheum Dis, 1992;51:713-6.

[73] Li C, Mu R, Lu XY, He J, Jia RL, Li ZG. Antilymphocyte antibodies in systemic lupus erythematosus: association with disease activity and lymphopenia. J Immunol Res, 2014;2014:672126.

[74] García-Valladares I, Atisha-Fregoso Y, Richaud-Patin Y, Jakez-Ocampo J, SotoVega E, Elías-López D et al. Diminished expression of complement regulatory proteins (CD55 and CD59) in lymphocytes from systemic lupus erythematosus patients with lymphopenia. Lupus, 2006;15:600-5.

[75] Massardo L, Metz C, Pardo E, Mezzano V, Babul M, Jarpa E et al. Autoantibodies against galectin-8: their specificity, association with lymphopenia in systemic lupus erythematosus and detection in rheumatoid arthritis and acute inflammation. Lupus, 2009;18:539-46.

[76] Messner RP, Lindström FD, Williams RC. Peripheral blood lymphocyte cell surface markers during the course of systemic lupus erythematosus. J Clin Invest, 1973;52:3046-56. 
[77] Wenzel J, Bauer R, Bieber T, Boehm I. Presence of antinuclear antibodies in patients with lupus erythematosus is correlated with diminished T-helper cells. Br J Dermatol, 2000;143:1100-1.

[78] Amasaki Y, Kobayashi S, Takeda T, Ogura N, Jodo S, Nakabayashi T et al. Upregulated expression of Fas antigen (CD95) by peripheral naive and memory $T$ cell subsets in patients with systemic lupus erythematosus (SLE): a possible mechanism for lymphopenia. Clin Exp Immunol, 1995;99:245-50.

[79] Odendahl M, Jacobi A, Hansen A, Feist E, Hiepe F, Burmester GR et al. Disturbed peripheral $B$ lymphocyte homeostasis in systemic lupus erythematosus. J Immunol, 2000;165:5970-9.

[80] Mirzayan MJ, Schmidt RE, Witte T. Prognostic parameters for flare in systemic lupus erythematosus. Rheumatology (Oxford), 2000;39:1316-9.

[81] Mathian A, Arnaud L, Adoue D, Agard C, Bader-Meunier B, Baudouin V et al. [Prevention of infections in adults and adolescents with systemic lupus erythematosus: Guidelines for the clinical practice based on the literature and expert opinion]. Rev Med Interne, 2016.

[82] Vananuvat $P$, Suwannalai $P$, Sungkanuparph $S$, Limsuwan T, Ngamjanyaporn $\mathrm{P}$, Janwityanujit S. Primary prophylaxis for Pneumocystis jirovecii pneumonia in patients with connective tissue diseases. Semin Arthritis Rheum, 2011;41:497-502.

[83] Boumpas DT, Chrousos GP, Wilder RL, Cupps TR, Balow JE. Glucocorticoid therapy for immune-mediated diseases: basic and clinical correlates. Ann Intern Med, 1993;119:1198-208.

[84] Lipp E, von Felten A, Sax H, Müller D, Berchtold P. Antibodies against platelet glycoproteins and antiphospholipid antibodies in autoimmune thrombocytopenia. Eur J Haematol, 1998;60:283-8.

[85] Michel M, Lee K, Piette JC, Fromont P, Schaeffer A, Bierling P et al. Platelet autoantibodies and lupus-associated thrombocytopenia. Br J Haematol, 2002;119:354-8.

[86] Ziakas PD, Routsias JG, Giannouli S, Tasidou A, Tzioufas AG, Voulgarelis M. Suspects in the tale of lupus-associated thrombocytopenia. Clin Exp Immunol, 2006;145:71-80.

[87] Rodeghiero F, Stasi R, Gernsheimer T, Michel M, Provan D, Arnold DM et al. Standardization of terminology, definitions and outcome criteria in immune thrombocytopenic purpura of adults and children: report from an international working group. Blood, 2009;113:2386-93.

[88] Wang F, Wang CL, Tan CT, Manivasagar M. Systemic lupus erythematosus in Malaysia: a study of 539 patients and comparison of prevalence and disease expression in different racial and gender groups. Lupus, 1997;6:248-53.

[89] Cervera R, Khamashta MA, Font J, Sebastiani GD, Gil A, Lavilla P et al. Morbidity and mortality in systemic lupus erythematosus during a 5-year period. A multicenter prospective study of 1,000 patients. European Working Party on Systemic Lupus Erythematosus. Medicine (Baltimore), 1999;78:16775.

[90] Mok CC, Lee KW, Ho CT, Lau CS, Wong RW. A prospective study of survival and prognostic indicators of systemic lupus erythematosus in a southern Chinese population. Rheumatology (Oxford), 2000;39:399-406. 
[91] Vilá LM, Alarcón GS, McGwin G, Friedman AW, Baethge BA, Bastian HM et al. Early clinical manifestations, disease activity and damage of systemic lupus erythematosus among two distinct US Hispanic subpopulations. Rheumatology (Oxford), 2004;43:358-63.

[92] Ziakas PD, Giannouli S, Zintzaras E, Tzioufas AG, Voulgarelis M. Lupus thrombocytopenia: clinical implications and prognostic significance. Ann Rheum Dis, 2005;64:1366-9.

[93] Drenkard C, Villa AR, Alarcón-Segovia D, Pérez-Vázquez ME. Influence of the antiphospholipid syndrome in the survival of patients with systemic lupus erythematosus. J Rheumatol, 1994;21:1067-72.

[94] Nossent JC, Swaak AJ. Prevalence and significance of haematological abnormalities in patients with systemic lupus erythematosus. Q J Med, 1991;80:605-12.

[95] Pujol M, Ribera A, Vilardell M, Ordi J, Feliu E. High prevalence of platelet autoantibodies in patients with systemic lupus erythematosus. $\mathrm{Br} \mathrm{J}$ Haematol, 1995;89:137-41.

[96] López-Soto A, Cervera R, Font J, Bové A, Reverter JC, Muñoz FJ et al. Isotype distribution and clinical significance of antibodies to cardiolipin, phosphatidic acid, phosphatidylinositol and phosphatidylserine in systemic lupus erythematosus: prospective analysis of a series of 92 patients. Clin Exp Rheumatol, 1997;15:143-9.

[97] Abu-Shakra M, Gladman DD, Urowitz MB, Farewell V. Anticardiolipin antibodies in systemic lupus erythematosus: clinical and laboratory correlations. Am J Med, 1995;99:624-8.

[98] Manoharan A, Williams NT, Sparrow R. Acquired amegakaryocytic thrombocytopenia: report of a case and review of literature. Q J Med, 1989;70:243-52.

[99] Katai M, Aizawa T, Ohara N, Hiramatsu K, Hashizume K, Yamada T et al. Acquired amegakaryocytic thrombocytopenic purpura with humoral inhibitory factor for megakaryocyte colony formation. Intern Med, 1994;33:147-9.

[100] Nagasawa T, Sakurai T, Kashiwagi H, Abe T. Cell-mediated amegakaryocytic thrombocytopenia associated with systemic lupus erythematosus. Blood, 1986;67:479-83.

[101] Kuwana M, Okazaki Y, Kajihara M, Kaburaki J, Miyazaki H, Kawakami Y et al. Autoantibody to c-Mpl (thrombopoietin receptor) in systemic lupus erythematosus: relationship to thrombocytopenia with megakaryocytic hypoplasia. Arthritis Rheum, 2002;46:2148-59.

[102] Füreder W, Firbas U, Nichol JL, Pistillo J, Winkler S, Hiesberger H et al. Serum thrombopoietin levels and anti-thrombopoietin antibodies in systemic lupus erythematosus. Lupus, 2002;11:221-6.

[103] Tsao BP, Grossman JM, Riemekasten G, Strong N, Kalsi J, Wallace DJ et al. Familiality and co-occurrence of clinical features of systemic lupus erythematosus. Arthritis Rheum, 2002;46:2678-85.

[104] Kaufman KM, Rankin J, Harley IT, Kelly JA, Harley JB, Scofield RH. A genetic marker within the CD44 gene confirms linkage at 11 p13 in African-American 
families with lupus stratified by thrombocytopenia, but genetic association with CD44 is not present. Genes Immun, 2002;3 Suppl 1:S86-8.

[105] Scofield RH, Bruner GR, Kelly JA, Kilpatrick J, Bacino D, Nath SK et al. Thrombocytopenia identifies a severe familial phenotype of systemic lupus erythematosus and reveals genetic linkages at $1 q 22$ and 11p13. Blood, 2003;101:992-7.

[106] Karpatkin S. Autoimmune thrombocytopenic purpura. Blood, 1980;56:32943.

[107] Reveille JD, Bartolucci A, Alarcón GS. Prognosis in systemic lupus erythematosus. Negative impact of increasing age at onset, black race, and thrombocytopenia, as well as causes of death. Arthritis Rheum, 1990;33:3748.

[108] Pistiner M, Wallace DJ, Nessim S, Metzger AL, Klinenberg JR. Lupus erythematosus in the 1980s: a survey of 570 patients. Semin Arthritis Rheum, 1991;21:55-64.

[109] Feinglass EJ, Arnett FC, Dorsch CA, Zizic TM, Stevens MB. Neuropsychiatric manifestations of systemic lupus erythematosus: diagnosis, clinical spectrum, and relationship to other features of the disease. Medicine (Baltimore), 1976;55:323-39.

[110] Miller MH, Urowitz MB, Gladman DD. The significance of thrombocytopenia in systemic lupus erythematosus. Arthritis Rheum, 1983;26:1181-6.

[111] Alger M, Alarcon-Segovia D, Rivero SJ. Hemolytic anemia and thrombocytopenic purpura: two related subsets of systemic lupus erythematosus. J Rheumatol, 1977;4:351-7.

[112] Neunert C, Lim W, Crowther M, Cohen A, Solberg L, Crowther MA et al. The American Society of Hematology 2011 evidence-based practice guideline for immune thrombocytopenia. Blood, 2011;117:4190-207.

[113] Hepburn AL, Narat S, Mason JC. The management of peripheral blood cytopenias in systemic lupus erythematosus. Rheumatology (Oxford), 2010;49:2243-54.

[114] Kimberly RP. Pulse methylprednisolone in SLE. Clin Rheum Dis, 1982;8:26178.

[115] Lurie DP, Kahaleh MB. Pulse corticosteroid therapy for refractory thrombocytopenia in systemic lupus erythematosus. J Rheumatol, 1982;9:311-4.

[116] Arnal C, Piette JC, Léone J, Taillan B, Hachulla E, Roudot-Thoraval F et al. Treatment of severe immune thrombocytopenia associated with systemic lupus erythematosus: 59 cases. J Rheumatol, 2002;29:75-83.

[117] Jacobs P, Wood L, Dent DM. Splenectomy and the thrombocytopenia of systemic lupus erythematosus. Ann Intern Med, 1986;105:971-2.

[118] Gruenberg JC, VanSlyck EJ, Abraham JP. Splenectomy in systemic lupus erythematosis. Am Surg, 1986;52:366-70.

[119] Hall S, McCormick JL, Greipp PR, Michet CJ, McKenna CH. Splenectomy does not cure the thrombocytopenia of systemic lupus erythematosus. Ann Intern Med, 1985;102:325-8.

[120] Hepburn AL, Davies KA. Infection and SLE. Ann Rheum Dis, 2002;61:668-9; author reply 9. 
[121] Braendstrup P, Bjerrum OW, Nielsen OJ, Jensen BA, Clausen NT, Hansen PB et al. Rituximab chimeric anti-CD20 monoclonal antibody treatment for adult refractory idiopathic thrombocytopenic purpura. Am J Hematol, 2005;78:27580.

[122] Jiang B, Li T, Guo L, Shen H, Ye S, Chen S. Efficacy and Safety of Rituximab in Systemic Lupus Erythematosus and Sjögren Syndrome Patients With Refractory Thrombocytopenia: A Retrospective Study of 21 Cases. J Clin Rheumatol, 2015;21:244-50.

[123] Wall BA, Weinblatt ME, Agudelo CA. Plasmapheresis in the treatment of resistant thrombocytopenia in systemic lupus erythematosus. South Med J, 1982;75:1277-8.

[124] Scully M, Hunt BJ, Benjamin S, Liesner R, Rose P, Peyvandi F et al. Guidelines on the diagnosis and management of thrombotic thrombocytopenic purpura and other thrombotic microangiopathies. Br J Haematol, 2012;158:323-35.

[125] Roriz M, Landais M, Desprez J, Barbet C, Azoulay E, Galicier L et al. Risk Factors for Autoimmune Diseases Development After Thrombotic Thrombocytopenic Purpura. Medicine (Baltimore), 2015;94:e1598.

[126] Letchumanan P, Ng HJ, Lee LH, Thumboo J. A comparison of thrombotic thrombocytopenic purpura in an inception cohort of patients with and without systemic lupus erythematosus. Rheumatology (Oxford), 2009;48:399403.

[127] Terrell DR, Williams LA, Vesely SK, Lämmle B, Hovinga JA, George JN. The incidence of thrombotic thrombocytopenic purpura-hemolytic uremic syndrome: all patients, idiopathic patients, and patients with severe ADAMTS-13 deficiency. J Thromb Haemost, 2005;3:1432-6.

[128] Devinsky O, Petito CK, Alonso DR. Clinical and neuropathological findings in systemic lupus erythematosus: the role of vasculitis, heart emboli, and thrombotic thrombocytopenic purpura. Ann Neurol, 1988;23:380-4.

[129] George JN, Nester CM. Syndromes of thrombotic microangiopathy. N Engl J Med, 2014;371:654-66.

[130] Moake JL, Rudy CK, Troll JH, Weinstein MJ, Colannino NM, Azocar J et al. Unusually large plasma factor VIII:von Willebrand factor multimers in chronic relapsing thrombotic thrombocytopenic purpura. N Engl J Med, 1982;307:1432-5.

[131] Ferrari S, Mudde GC, Rieger M, Veyradier A, Kremer Hovinga JA, Scheiflinger F. IgG subclass distribution of anti-ADAMTS13 antibodies in patients with acquired thrombotic thrombocytopenic purpura. J Thromb Haemost, 2009;7:1703-10.

[132] Pos W, Sorvillo N, Fijnheer R, Feys HB, Kaijen PH, Vidarsson G et al. Residues Arg568 and Phe592 contribute to an antigenic surface for anti-ADAMTS13 antibodies in the spacer domain. Haematologica, 2011;96:1670-7.

[133] Enami T, Suzuki T, Ito S, Yoshimi A, Sugihara M, Mamura M et al. Successful treatment of refractory thrombotic thrombocytopenic purpura with cyclosporine and corticosteroids in a patient with systemic lupus erythematosus and antibodies to ADAMTS13. Intern Med, 2007;46:1033-7. 
[134] Arbuckle MR, McClain MT, Rubertone MV, Scofield RH, Dennis GJ, James JA et al. Development of autoantibodies before the clinical onset of systemic lupus erythematosus. N Engl J Med, 2003;349:1526-33.

[135] Amoura Z, Costedoat-Chalumeau N, Veyradier A, Wolf M, Ghillani-Dalbin P, Cacoub $\mathrm{P}$ et al. Thrombotic thrombocytopenic purpura with severe ADAMTS13 deficiency in two patients with primary antiphospholipid syndrome. Arthritis Rheum, 2004;50:3260-4.

[136] George JN, Vesely SK, James JA. Overlapping features of thrombotic thrombocytopenic purpura and systemic lupus erythematosus. South Med J, 2007;100:512-4.

[137] Stricker RB, Davis JA, Gershow J, Yamamoto KS, Kiprov DD. Thrombotic thrombocytopenic purpura complicating systemic lupus erythematosus. Case report and literature review from the plasmapheresis era. J Rheumatol, 1992;19:1469-73.

[138] Vaidya S, Abul-ezz S, Lipsmeyer E. Thrombotic thrombocytopenic purpura and systemic lupus erythematosus. Scand J Rheumatol, 2001;30:308-10.

[139] Jiang H, An X, Li Y, Sun Y, Shen G, Tu Y et al. Clinical features and prognostic factors of thrombotic thrombocytopenic purpura associated with systemic lupus erythematosus: a literature review of 105 cases from 1999 to 2011. Clin Rheumatol, 2014;33:419-27.

[140] Musio F, Bohen EM, Yuan CM, Welch PG. Review of thrombotic thrombocytopenic purpura in the setting of systemic lupus erythematosus. Semin Arthritis Rheum, 1998;28:1-19.

[141] Kwok SK, Ju JH, Cho CS, Kim HY, Park SH. Thrombotic thrombocytopenic purpura in systemic lupus erythematosus: risk factors and clinical outcome: a single centre study. Lupus, 2009;18:16-21.

[142] John ML, Scharrer I. Autoimmune disorders in patients with idiopathic thrombotic thrombocytopenic purpura. Hamostaseologie, 2012;32 Suppl 1:S86-9.

[143] Brunner HI, Freedman M, Silverman ED. Close relationship between systemic lupus erythematosus and thrombotic thrombocytopenic purpura in childhood. Arthritis Rheum, 1999;42:2346-55.

[144] Zheng T, Chunlei L, Zhen W, Ping L, Haitao Z, Weixin H et al. Clinicalpathological features and prognosis of thrombotic thrombocytopenic purpura in patients with lupus nephritis. Am J Med Sci, 2009;338:343-7.

[145] Rock GA, Shumak KH, Buskard NA, Blanchette VS, Kelton JG, Nair RC et al. Comparison of plasma exchange with plasma infusion in the treatment of thrombotic thrombocytopenic purpura. Canadian Apheresis Study Group. N Engl J Med, 1991;325:393-7.

[146] Aleem A, Al-Sugair S. Thrombotic thrombocytopenic purpura associated with systemic lupus erythematosus. Acta Haematol, 2006;115:68-73.

[147] Vasoo S, Thumboo J, Fong KY. Thrombotic thrombocytopenic purpura in systemic lupus erythematosus: disease activity and the use of cytotoxic drugs. Lupus, 2002;11:443-50.

[148] Pérez-Sánchez I, Anguita J, Pintado T. Use of cyclophosphamide in the treatment of thrombotic thrombocytopenic purpura complicating systemic lupus erythematosus: report of two cases. Ann Hematol, 1999;78:285-7. 
[149] Limal N, Cacoub P, Sène D, Guichard I, Piette JC. Rituximab for the treatment of thrombotic thrombocytopenic purpura in systemic lupus erythematosus. Lupus, 2008;17:69-71.

[150] Hundae A, Peskoe S, Grimsley E, Patel S. Rituximab therapy for refractory thrombotic thrombocytopenic purpura and autoimmune-mediated thrombocytopenia in systemic lupus erythematosus. South Med J, 2008;101:943-4.

[151] Karimifar M. Thrombotic thrombocytopenic purpura treated with rituximab in systemic lupus erythematosus. J Renal Inj Prev, 2012;1:53-4.

[152] Niaz FA, Aleem A. Response to rituximab in a refractory case of thrombotic thrombocytopenic purpura associated with systemic lupus erythematosus. Saudi J Kidney Dis Transpl, 2010;21:109-12.

[153] Kafle P, Malakoff GL. Coexistence of systemic lupus erythematosus and thrombotic thrombocytopenic purpura: a case report. Tenn Med, 2012;105:37-8.

[154] Abid N. Thrombocytosis in a patient with systemic lupus. J Pak Med Assoc, 2013;63:1305-6.

[155] Childs JC, Adelizzi RA, Dabrow MB, Freed N. Splenic hypofunction in systemic lupus erythematosus. J Am Osteopath Assoc, 1994;94:414-5.

[156] Castellino G, Govoni M, Prandini N, Limpido G, Bernardi S, Campione D et al. Thrombocytosis in systemic lupus erythematosus: a possible clue to autosplenectomy? J Rheumatol, 2007;34:1497-501.

[157] Santilli D, Govoni M, Prandini N, Rizzo N, Trotta F. Autosplenectomy and antiphospholipid antibodies in systemic lupus erythematosus: A pathogenetic relationship? Semin Arthritis Rheum, 2003;33:125-33.

[158] Wanitpongpun C, Teawtrakul N, Mahakkanukrauh A, Siritunyaporn S, Sirijerachai $\mathrm{C}$, Chansung K. Bone marrow abnormalities in systemic lupus erythematosus with peripheral cytopenia. Clin Exp Rheumatol, 2012;30:8259.

[159] Voulgarelis M, Giannouli S, Tasidou A, Anagnostou D, Ziakas PD, Tzioufas AG. Bone marrow histological findings in systemic lupus erythematosus with hematologic abnormalities: a clinicopathological study. Am J Hematol, 2006;81:590-7.

[160] Kuter DJ, Bain B, Mufti G, Bagg A, Hasserjian RP. Bone marrow fibrosis: pathophysiology and clinical significance of increased bone marrow stromal fibres. Br J Haematol, 2007;139:351-62.

[161] Yablonski-Peretz T, Sulkes A, Polliack A, Weshler Z, Okon E, Catane R. Secondary myelofibrosis with metastatic breast cancer simulating agnogenic myeloid metaplasia: report of a case and review of the literature. Med Pediatr Oncol, 1985;13:92-6.

[162] Schmidt U, Ruwe M, Leder LD. Multiple myeloma with bone marrow biopsy features simulating concomitant chronic idiopathic myelofibrosis. Nouv Rev Fr Hematol, 1995;37:159-63.

[163] Cavalcant J, Shadduck RK, Winkelstein A, Zeigler Z, Mendelow H. Red-cell hypoplasia and increased bone marrow reticulin in systemic lupus erythematosus: reversal with corticosteroid therapy. Am J Hematol, 1978;5:253-63. 
[164] Paquette RL, Meshkinpour A, Rosen PJ. Autoimmune myelofibrosis. A steroidresponsive cause of bone marrow fibrosis associated with systemic lupus erythematosus. Medicine (Baltimore), 1994;73:145-52.

[165] Chalayer E, Ffrench M, Cathébras P. Bone marrow fibrosis as a feature of systemic lupus erythematosus: a case report and literature review. Springerplus, 2014;3:349.

[166] Le Bousse-Kerdilès MC, Martyré MC, Samson M. Cellular and molecular mechanisms underlying bone marrow and liver fibrosis: a review. Eur Cytokine Netw, 2008;19:69-80.

[167] Ramakrishna R, Kyle PW, Day PJ, Manoharan A. Evans' syndrome, myelofibrosis and systemic lupus erythematosus: role of procollagens in myelofibrosis. Pathology, 1995;27:255-9.

[168] Kiss E, Gál I, Simkovics E, Kiss A, Bányai A, Szakáll S et al. Myelofibrosis in systemic lupus erythematosus. Leuk Lymphoma, 2000;39:661-5.

[169] Tefferi A, Lasho TL, Jimma T, Finke CM, Gangat N, Vaidya R et al. One thousand patients with primary myelofibrosis: the mayo clinic experience. Mayo Clin Proc, 2012;87:25-33.

[170] Gotlib J. JAK inhibition in the myeloproliferative neoplasms: lessons learned from the bench and bedside. Hematology Am Soc Hematol Educ Program, 2013;2013:529-37.

[171] Verstovsek S, Mesa RA, Gotlib J, Levy RS, Gupta V, DiPersio JF et al. A doubleblind, placebo-controlled trial of ruxolitinib for myelofibrosis. N Engl J Med, 2012;366:799-807.

[172] Verstovsek S, Mesa RA, Gotlib J, Levy RS, Gupta V, DiPersio JF et al. Efficacy, safety and survival with ruxolitinib in patients with myelofibrosis: results of a median 2-year follow-up of COMFORT-I. Haematologica, 2013;98:1865-71.

[173] Verstovsek S, Mesa RA, Gotlib J, Levy RS, Gupta V, DiPersio JF et al. Efficacy, safety, and survival with ruxolitinib in patients with myelofibrosis: results of a median 3-year follow-up of COMFORT-I. Haematologica, 2015;100:479-88.

[174] Aharon A, Levy Y, Bar-Dayan Y, Afek A, Zandman-Goddard G, Skurnik Y et al. Successful treatment of early secondary myelofibrosis in SLE with IVIG. Lupus, 1997;6:408-11.

[175] Ungprasert P, Chowdhary VR, Davis MD, Makol A. Autoimmune myelofibrosis with pancytopenia as a presenting manifestation of systemic lupus erythematosus responsive to mycophenolate mofetil. Lupus, 2016;25:427-30.

[176] Parodi A, Davì S, Pringe AB, Pistorio A, Ruperto N, Magni-Manzoni S et al. Macrophage activation syndrome in juvenile systemic lupus erythematosus: a multinational multicenter study of thirty-eight patients. Arthritis Rheum, 2009;60:3388-99.

[177] Li X, Qu B, Nie Y, Zhu G, Li W, Mu F. Clinical features of macrophage activation syndrome in the adult northern Chinese population. Lupus, 2014;23:785-92.

[178] Pringe A, Trail L, Ruperto N, Buoncompagni A, Loy A, Breda L et al. Macrophage activation syndrome in juvenile systemic lupus erythematosus: an under-recognized complication? Lupus, 2007;16:587-92.

[179] Dhote R, Simon J, Papo T, Detournay B, Sailler L, Andre MH et al. Reactive hemophagocytic syndrome in adult systemic disease: report of twenty-six cases and literature review. Arthritis Rheum, 2003;49:633-9. 
[180] Lambotte O, Khellaf M, Harmouche H, Bader-Meunier B, Manceron V, Goujard $C$ et al. Characteristics and long-term outcome of 15 episodes of systemic lupus erythematosus-associated hemophagocytic syndrome. Medicine (Baltimore), 2006;85:169-82.

[181] Torres Jiménez A, Solís Vallejo E, Zeferino Cruz M, Céspedes Cruz A, Sánchez Jara B. Macrophage activation syndrome as the initial manifestation of severe juvenile onset systemic lupus erythematosus. Favorable response to cyclophosphamide. Reumatol Clin, 2014;10:331-5.

[182] Qian J, Yang CD. Hemophagocytic syndrome as one of main manifestations in untreated systemic lupus erythematosus: two case reports and literature review. Clin Rheumatol, 2007;26:807-10.

[183] EVANS RS, DUANE RT. Acquired hemolytic anemia; the relation of erythrocyte antibody production to activity of the disease; the significance of thrombocytopenia and leukopenia. Blood, 1949;4:1196-213.

[184] Michel M, Chanet V, Dechartres A, Morin AS, Piette JC, Cirasino L et al. The spectrum of Evans syndrome in adults: new insight into the disease based on the analysis of 68 cases. Blood, 2009;114:3167-72.

[185] Cervera H, Jara L, Pizarro S, Enkerlin HL, Fernandez M, Medina F et al. Danazol for systemic lupus erythematosus with refractory autoimmune thrombocytopenia or Evans' syndrome. J Rheumatol, 1995;22:1867-71.

[186] Gonzalez-Nieto JA, Martin-Suarez I, Quattrino S, Ortiz-Lopez E, MuñozBeamud FR, Colchero-Fernández J et al. The efficacy of romiplostim in the treatment of severe thrombocytopenia associated to Evans syndrome refractory to rituximab. Lupus, 2011;20:1321-3.

[187] Tamimoto Y, Horiuchi T, Tsukamoto H, Otsuka J, Mitoma H, Kimoto Y et al. A dose-escalation study of rituximab for treatment of systemic lupus erythematosus and Evans' syndrome: immunological analysis of B cells, T cells and cytokines. Rheumatology (Oxford), 2008;47:821-7.

[188] Cervera R, Khamashta MA, Font J, Sebastiani GD, Gil A, Lavilla P et al. Morbidity and mortality in systemic lupus erythematosus during a 10 -year period: a comparison of early and late manifestations in a cohort of 1,000 patients. Medicine (Baltimore), 2003;82:299-308.

[189] Pauzner R, Rosner E, Many A. Circulating anticoagulant in systemic lupus erythematosus: clinical manifestations. Acta Haematol, 1986;76:90-4.

[190] Love PE, Santoro SA. Antiphospholipid antibodies: anticardiolipin and the lupus anticoagulant in systemic lupus erythematosus (SLE) and in non-SLE disorders. Prevalence and clinical significance. Ann Intern Med, 1990;112:682-98.

[191] Mok CC, Tang SS, To CH, Petri M. Incidence and risk factors of thromboembolism in systemic lupus erythematosus: a comparison of three ethnic groups. Arthritis Rheum, 2005;52:2774-82.

[192] Qushmaq K, Esdaile J, Devine DV. Thrombosis in systemic lupus erythematosus: the role of antiphospholipid antibody. Arthritis Care Res, 1999;12:212-9.

[193] Feinbloom D, Bauer KA. Assessment of hemostatic risk factors in predicting arterial thrombotic events. Arterioscler Thromb Vasc Biol, 2005;25:2043-53. 
[194] Kiraz S, Ertenli I, Benekli M, Haznedaroğlu IC, Calgüneri M, Celik I et al. Clinical significance of hemostatic markers and thrombomodulin in systemic lupus erythematosus: evidence for a prothrombotic state. Lupus, 1999;8:737-41.

[195] Petri M. Thrombosis and systemic lupus erythematosus: the Hopkins Lupus Cohort perspective. Scand J Rheumatol, 1996;25:191-3.

[196] Belmont HM, Abramson SB, Lie JT. Pathology and pathogenesis of vascular injury in systemic lupus erythematosus. Interactions of inflammatory cells and activated endothelium. Arthritis Rheum, 1996;39:9-22.

[197] Manger K, Manger B, Repp R, Geisselbrecht M, Geiger A, Pfahlberg A et al. Definition of risk factors for death, end stage renal disease, and thromboembolic events in a monocentric cohort of 338 patients with systemic lupus erythematosus. Ann Rheum Dis, 2002;61:1065-70.

[198] Toloza SM, Uribe AG, McGwin G, Alarcón GS, Fessler BJ, Bastian HM et al. Systemic lupus erythematosus in a multiethnic US cohort (LUMINA). XXIII. Baseline predictors of vascular events. Arthritis Rheum, 2004;50:3947-57.

[199] Manzi S, Meilahn EN, Rairie JE, Conte CG, Medsger TA, Jansen-McWilliams L et al. Age-specific incidence rates of myocardial infarction and angina in women with systemic lupus erythematosus: comparison with the Framingham Study. Am J Epidemiol, 1997;145:408-15.

[200] Ghaussy NO, Sibbitt W, Bankhurst AD, Qualls CR. Cigarette smoking and disease activity in systemic lupus erythematosus. J Rheumatol, 2003;30:121521.

[201] Danowski A, de Azevedo MN, de Souza Papi JA, Petri M. Determinants of risk for venous and arterial thrombosis in primary antiphospholipid syndrome and in antiphospholipid syndrome with systemic lupus erythematosus. J Rheumatol, 2009;36:1195-9.

[202] Calvo-Alén J, Toloza SM, Fernández M, Bastian HM, Fessler BJ, Roseman JM et al. Systemic lupus erythematosus in a multiethnic US cohort (LUMINA). XXV. Smoking, older age, disease activity, lupus anticoagulant, and glucocorticoid dose as risk factors for the occurrence of venous thrombosis in lupus patients. Arthritis Rheum, 2005;52:2060-8.

[203] Roman MJ, Shanker BA, Davis A, Lockshin MD, Sammaritano L, Simantov R et al. Prevalence and correlates of accelerated atherosclerosis in systemic lupus erythematosus. N Engl J Med, 2003;349:2399-406.

[204] Kaiser R, Cleveland CM, Criswell LA. Risk and protective factors for thrombosis in systemic lupus erythematosus: results from a large, multiethnic cohort. Ann Rheum Dis, 2009;68:238-41.

[205] Gustafsson JT, Simard JF, Gunnarsson I, Elvin K, Lundberg IE, Hansson LO et al. Risk factors for cardiovascular mortality in patients with systemic lupus erythematosus, a prospective cohort study. Arthritis Res Ther, 2012;14:R46.

[206] Petri M. The lupus anticoagulant is a risk factor for myocardial infarction (but not atherosclerosis): Hopkins Lupus Cohort. Thromb Res, 2004;114:593-5.

[207] Mok CC, Lau CS, Wong RW. Neuropsychiatric manifestations and their clinical associations in southern Chinese patients with systemic lupus erythematosus. J Rheumatol, 2001;28:766-71.

[208] Miyakis S, Lockshin MD, Atsumi T, Branch DW, Brey RL, Cervera R et al. International consensus statement on an update of the classification criteria 
for definite antiphospholipid syndrome (APS). J Thromb Haemost, 2006;4:295-306.

[209] Amoroso A, Mitterhofer AP, Del Porto F, Garzia P, Ferri GM, Galluzzo S et al. Antibodies to anionic phospholipids and anti-beta2-GPI: association with thrombosis and thrombocytopenia in systemic lupus erythematosus. Hum Immunol, 2003;64:265-73.

[210] Arnout J, Vermylen J. Current status and implications of autoimmune antiphospholipid antibodies in relation to thrombotic disease. J Thromb Haemost, 2003;1:931-42.

[211] Pierangeli SS, Vega-Ostertag ME, González EB. New targeted therapies for treatment of thrombosis in antiphospholipid syndrome. Expert Rev Mol Med, 2007;9:1-15.

[212] Ruiz-Irastorza G, Crowther M, Branch W, Khamashta MA. Antiphospholipid syndrome. Lancet, 2010;376:1498-509.

[213] de Groot PG, Derksen RH. Pathophysiology of the antiphospholipid syndrome. J Thromb Haemost, 2005;3:1854-60.

[214] Rand JH, Wu XX, Quinn AS, Taatjes DJ. The annexin A5-mediated pathogenic mechanism in the antiphospholipid syndrome: role in pregnancy losses and thrombosis. Lupus, 2010;19:460-9.

[215] Frank M, Sodin-Semrl S, Rozman B, Potocnik M, Kralj-Iglic V. Effects of lowmolecular-weight heparin on adhesion and vesiculation of phospholipid membranes: a possible mechanism for the treatment of hypercoagulability in antiphospholipid syndrome. Ann N Y Acad Sci, 2009;1173:874-86.

[216] Krone KA, Allen KL, McCrae KR. Impaired fibrinolysis in the antiphospholipid syndrome. Curr Rheumatol Rep, 2010;12:53-7.

[217] De Laat B, Derksen RH, Reber G, Musial J, Swadzba J, Bozic B et al. An international multicentre-laboratory evaluation of a new assay to detect specifically lupus anticoagulants dependent on the presence of anti-beta2glycoprotein autoantibodies. J Thromb Haemost, 2011;9:149-53.

[218] Fischetti F, Durigutto P, Pellis V, Debeus A, Macor P, Bulla R et al. Thrombus formation induced by antibodies to beta2-glycoprotein I is complement dependent and requires a priming factor. Blood, 2005;106:2340-6.

[219] Vega-Ostertag M, Liu X, Kwan-Ki H, Chen P, Pierangeli S. A human monoclonal antiprothrombin antibody is thrombogenic in vivo and upregulates expression of tissue factor and E-selectin on endothelial cells. Br J Haematol, 2006;135:214-9.

[220] Salmon JE, de Groot PG. Pathogenic role of antiphospholipid antibodies. Lupus, 2008;17:405-11.

[221] Pierangeli SS, Girardi G, Vega-Ostertag M, Liu X, Espinola RG, Salmon J. Requirement of activation of complement C3 and C5 for antiphospholipid antibody-mediated thrombophilia. Arthritis Rheum, 2005;52:2120-4.

[222] Lood C, Eriksson S, Gullstrand B, Jönsen A, Sturfelt G, Truedsson L et al. Increased C1q, C4 and C3 deposition on platelets in patients with systemic lupus erythematosus--a possible link to venous thrombosis? Lupus, 2012;21:1423-32. 
[223] Navratil JS, Manzi S, Kao AH, Krishnaswami S, Liu CC, Ruffing MJ et al. Platelet C4d is highly specific for systemic lupus erythematosus. Arthritis Rheum, 2006;54:670-4.

[224] Dhillon PK, Adams MJ. Thrombosis in systemic lupus erythematosus: role of impaired fibrinolysis. Semin Thromb Hemost, 2013;39:434-40.

[225] Lane DA, Mannucci PM, Bauer KA, Bertina RM, Bochkov NP, Boulyjenkov V et al. Inherited thrombophilia: Part 1. Thromb Haemost, 1996;76:651-62.

[226] Keeling DM, Campbell SJ, Mackie IJ, Machin SJ, Isenberg DA. Total and free protein S in systemic lupus erythematosus. Thromb Res, 1990;60:237-40.

[227] Atsumi T, Khamashta MA, Amengual O, Donohoe S, Mackie I, Ichikawa K et al. Binding of anticardiolipin antibodies to protein $\mathrm{C}$ via beta2-glycoprotein I (beta2-GPI): a possible mechanism in the inhibitory effect of antiphospholipid antibodies on the protein C system. Clin Exp Immunol, 1998;112:325-33.

[228] Tektonidou MG, Laskari K, Panagiotakos DB, Moutsopoulos HM. Risk factors for thrombosis and primary thrombosis prevention in patients with systemic lupus erythematosus with or without antiphospholipid antibodies. Arthritis Rheum, 2009;61:29-36.

[229] Tarr T, Lakos G, Bhattoa HP, Soltesz P, Shoenfeld Y, Szegedi G et al. Clinical thrombotic manifestations in SLE patients with and without antiphospholipid antibodies: a 5-year follow-up. Clin Rev Allergy Immunol, 2007;32:131-7.

[230] Erkan D, Yazici Y, Peterson MG, Sammaritano L, Lockshin MD. A crosssectional study of clinical thrombotic risk factors and preventive treatments in antiphospholipid syndrome. Rheumatology (Oxford), 2002;41:924-9.

[231] Bertsias GK, loannidis JP, Aringer M, Bollen E, Bombardieri S, Bruce IN et al. EULAR recommendations for the management of systemic lupus erythematosus with neuropsychiatric manifestations: report of a task force of the EULAR standing committee for clinical affairs. Ann Rheum Dis, 2010;69:2074-82.

[232] Wallace DJ, Linker-Israeli M, Metzger AL, Stecher VJ. The relevance of antimalarial therapy with regard to thrombosis, hypercholesterolemia and cytokines in SLE. Lupus, 1993;2 Suppl 1:S13-5.

[233] Yoon KH. Sufficient evidence to consider hydroxychloroquine as an adjunct therapy in antiphospholipid antibody (Hughes') syndome. J Rheumatol, 2002;29:1574-5.

[234] Ho KT, Ahn CW, Alarcón GS, Baethge BA, Tan FK, Roseman J et al. Systemic lupus erythematosus in a multiethnic cohort (LUMINA): XXVIII. Factors predictive of thrombotic events. Rheumatology (Oxford), 2005;44:1303-7.

[235] Pierangeli SS, Vega-Ostertag M, Harris EN. Intracellular signaling triggered by antiphospholipid antibodies in platelets and endothelial cells: a pathway to targeted therapies. Thromb Res, 2004;114:467-76.

[236] Edwards MH, Pierangeli S, Liu X, Barker JH, Anderson G, Harris EN. Hydroxychloroquine reverses thrombogenic properties of antiphospholipid antibodies in mice. Circulation, 1997;96:4380-4.

[237] Finazzi G, Brancaccio V, Moia M, Ciaverella N, Mazzucconi MG, Schinco PC et al. Natural history and risk factors for thrombosis in 360 patients with antiphospholipid antibodies: a four-year prospective study from the Italian Registry. Am J Med, 1996;100:530-6. 
[238] Krnic-Barrie S, O'Connor CR, Looney SW, Pierangeli SS, Harris EN. A retrospective review of 61 patients with antiphospholipid syndrome. Analysis of factors influencing recurrent thrombosis. Arch Intern Med, 1997;157:21018.

[239] Rosove MH, Brewer PM. Antiphospholipid thrombosis: clinical course after the first thrombotic event in 70 patients. Ann Intern Med, 1992;117:303-8.

[240] Lim W, Crowther MA, Eikelboom JW. Management of antiphospholipid antibody syndrome: a systematic review. JAMA, 2006;295:1050-7.

[241] Khamashta MA, Cuadrado MJ, Mujic F, Taub NA, Hunt BJ, Hughes GR. The management of thrombosis in the antiphospholipid-antibody syndrome. $\mathrm{N}$ Engl J Med, 1995;332:993-7.

[242] Finazzi G, Marchioli R, Brancaccio V, Schinco P, Wisloff F, Musial J et al. A randomized clinical trial of high-intensity warfarin vs. conventional antithrombotic therapy for the prevention of recurrent thrombosis in patients with the antiphospholipid syndrome (WAPS). J Thromb Haemost, 2005;3:848-53.

[243] Crowther MA, Ginsberg JS, Julian J, Denburg J, Hirsh J, Douketis J et al. A comparison of two intensities of warfarin for the prevention of recurrent thrombosis in patients with the antiphospholipid antibody syndrome. N Engl J Med, 2003;349:1133-8.

[244] Ruiz-Irastorza G, Hunt BJ, Khamashta MA. A systematic review of secondary thromboprophylaxis in patients with antiphospholipid antibodies. Arthritis Rheum, 2007;57:1487-95.

[245] Kearon C, Kahn SR, Agnelli G, Goldhaber S, Raskob GE, Comerota AJ et al. Antithrombotic therapy for venous thromboembolic disease: American College of Chest Physicians Evidence-Based Clinical Practice Guidelines (8th Edition). Chest, 2008;133:454S-545S.

[246] Crowther M, Crowther MA. Intensity of warfarin coagulation in the antiphospholipid syndrome. Curr Rheumatol Rep, 2010;12:64-9.

[247] Dentali F, Manfredi E, Crowther M, Ageno W. Long-duration therapy with low molecular weight heparin in patients with antiphospholipid antibody syndrome resistant to warfarin therapy. J Thromb Haemost, 2005;3:2121-3.

[248] Betancur JF, Bonilla-Abadía F, Hormaza AA, Jaramillo FJ, Cañas CA, Tobón GJ. Direct oral anticoagulants in antiphospholipid syndrome: a real life case series. Lupus, 2016;25:658-62.

[249] Signorelli F, Nogueira F, Domingues V, Mariz HA, Levy RA. Thrombotic events in patients with antiphospholipid syndrome treated with rivaroxaban: a series of eight cases. Clin Rheumatol, 2016;35:801-5.

[250] Cohen H, Doré CJ, Clawson S, Hunt BJ, Isenberg D, Khamashta M et al. Rivaroxaban in antiphospholipid syndrome (RAPS) protocol: a prospective, randomized controlled phase II/III clinical trial of rivaroxaban versus warfarin in patients with thrombotic antiphospholipid syndrome, with or without SLE. Lupus, 2015;24:1087-94.

[251] Cohen H. I140 What's New in the Management of Thrombotic Antiphospholipid Syndrome? Rheumatology, 2016;55:i28.

[252] Woller SC, Stevens SM, Kaplan DA, Branch DW, Aston VT, Wilson EL et al. Apixaban for the Secondary Prevention of Thrombosis Among Patients With 
Antiphospholipid Syndrome: Study Rationale and Design (ASTRO-APS). Clin Appl Thromb Hemost, 2016;22:239-47.

[253] Pengo V, Banzato A, Bison E, Zoppellaro G, Padayattil Jose S, Denas G. Efficacy and safety of rivaroxaban vs warfarin in high-risk patients with antiphospholipid syndrome: Rationale and design of the Trial on Rivaroxaban in AntiPhospholipid Syndrome (TRAPS) trial. Lupus, 2016;25:301-6.

[254] Melander C, Sallée M, Trolliet P, Candon S, Belenfant X, Daugas E et al. Rituximab in severe lupus nephritis: early B-cell depletion affects long-term renal outcome. Clin J Am Soc Nephrol, 2009;4:579-87.

[255] Kumar D, Roubey RA. Use of rituximab in the antiphospholipid syndrome. Curr Rheumatol Rep, 2010;12:40-4.

[256] Pierangeli SS, Erkan D. Antiphospholipid syndrome treatment beyond anticoagulation: are we there yet? Lupus, 2010;19:475-85.

[257] Mak A, Mok CC. Mycophenolate mofetil for refractory haemolytic anemia in systemic lupus erythematosus. Lupus, 2005;14:856-8.

[258] Emilia G, Messora C, Longo G, Bertesi M. Long-term salvage treatment by cyclosporin in refractory autoimmune haematological disorders. $\mathrm{Br} \mathrm{J}$ Haematol, 1996;93:341-4.

[259] Moyo VM, Smith D, Brodsky I, Crilley P, Jones RJ, Brodsky RA. High-dose cyclophosphamide for refractory autoimmune hemolytic anemia. Blood, 2002;100:704-6.

[260] CHERTKOW G, DACIE JV. Results of splenectomy in auto-immune haemolytic anaemia. Br J Haematol, 1956;2:237-49.

[261] Rivero SJ, Alger M, Alarcón-Segovia D. Splenectomy for hemocytopenia in systemic lupus erythematosus. A controlled appraisal. Arch Intern Med, 1979;139:773-6.

[262] Akpek G, McAneny D, Weintraub L. Comparative response to splenectomy in Coombs-positive autoimmune hemolytic anemia with or without associated disease. Am J Hematol, 1999;61:98-102.

[263] Flores G, Cunningham-Rundles C, Newland AC, Bussel JB. Efficacy of intravenous immunoglobulin in the treatment of autoimmune hemolytic anemia: results in 73 patients. Am J Hematol, 1993;44:237-42.

[264] Pignon JM, Poirson E, Rochant H. Danazol in autoimmune haemolytic anaemia. Br J Haematol, 1993;83:343-5.

[265] Ruivard M, Tournilhac O, Montel S, Fouilhoux AC, Quainon F, Lénat A et al. Plasma exchanges do not increase red blood cell transfusion efficiency in severe autoimmune hemolytic anemia: a retrospective case-control study. J Clin Apher, 2006;21:202-6.

[266] Zecca M, Nobili B, Ramenghi U, Perrotta S, Amendola G, Rosito P et al. Rituximab for the treatment of refractory autoimmune hemolytic anemia in children. Blood, 2003;101:3857-61.

[267] Abdwani R, Mani R. Anti-CD20 monoclonal antibody in acute life threatening haemolytic anaemia complicating childhood onset SLE. Lupus, 2009;18:460-4.

[268] Zecca M, De Stefano P, Nobili B, Locatelli F. Anti-CD20 monoclonal antibody for the treatment of severe, immune-mediated, pure red cell aplasia and hemolytic anemia. Blood, 2001;97:3995-7. 
[269] Provan D, Butler T, Evangelista ML, Amadori S, Newland AC, Stasi R. Activity and safety profile of low-dose rituximab for the treatment of autoimmune cytopenias in adults. Haematologica, 2007;92:1695-8.

[270] Dierickx D, Verhoef G, Van Hoof A, Mineur P, Roest A, Triffet A et al. Rituximab in auto-immune haemolytic anaemia and immune thrombocytopenic purpura: a Belgian retrospective multicentric study. J Intern Med, 2009;266:484-91.

[271] Birgens H, Frederiksen H, Hasselbalch HC, Rasmussen IH, Nielsen OJ, Kjeldsen L et al. A phase III randomized trial comparing glucocorticoid monotherapy versus glucocorticoid and rituximab in patients with autoimmune haemolytic anaemia. Br J Haematol, 2013;163:393-9.

[272] Marino C, Cook P. Danazol for lupus thrombocytopenia. Arch Intern Med, 1985;145:2251-2.

[273] Blanco R, Martinez-Taboada VM, Rodriguez-Valverde V, Sanchez-Andrade A, González-Gay MA. Successful therapy with danazol in refractory autoimmune thrombocytopenia associated with rheumatic diseases. Br J Rheumatol, 1997;36:1095-9.

[274] West SG, Johnson SC. Danazol for the treatment of refractory autoimmune thrombocytopenia in systemic lupus erythematosus. Ann Intern Med, 1988;108:703-6.

[275] Insiripong S, Chanchairujira T, Bumpenboon T. Danazol for thrombocytopenia in pregnancy with underlying systemic lupus erythematosus. J Med Assoc Thai, 1996;79:330-2.

[276] Boumpas DT, Barez S, Klippel JH, Balow JE. Intermittent cyclophosphamide for the treatment of autoimmune thrombocytopenia in systemic lupus erythematosus. Ann Intern Med, 1990;112:674-7.

[277] Park HJ, Kang MI, Kang Y, Chung SJ, Lee SW, Park YB et al. Two cases of refractory thrombocytopenia in systemic lupus erythematosus that responded to intravenous low-dose cyclophosphamide. J Korean Med Sci, 2013;28:472-5.

[278] Vasoo S, Thumboo J, Fong KY. Refractory immune thrombocytopenia in systemic lupus erythematosus: response to mycophenolate mofetil. Lupus, 2003;12:630-2.

[279] Chang HK. Successful treatment of refractory thrombocytopenia with mycophenolate mofetil in a patient with systemic lupus erythematosus. J Korean Med Sci, 2005;20:883-5.

[280] Dang Do AN, Umoren RA, Tarvin SE, Heilbrunn BR, Mahajerin A, Bowyer SL. Systemic lupus erythematosus in a 3-month old male presenting as thrombocytopenia. Lupus, 2011;20:527-30.

[281] Goebel KM, Gassel WD, Goebel FD. Evaluation of azathioprine in autoimmune thrombocytopenia and lupus erythematosus. Scand J Haematol, 1973;10:2834.

[282] Abu-Shakra M, Shoenfeld Y. Azathioprine therapy for patients with systemic lupus erythematosus. Lupus, 2001;10:152-3.

[283] Quartuccio L, Sacco S, Franzolini N, Perin A, Ferraccioli G, De Vita S. Efficacy of cyclosporin-A in the long-term management of thrombocytopenia associated with systemic lupus erythematosus. Lupus, 2006;15:76-9. 
[284] Manger K, Kalden JR, Manger B. Cyclosporin A in the treatment of systemic lupus erythematosus: results of an open clinical study. Br J Rheumatol, 1996;35:669-75.

[285] Sugiyama M, Ogasawara H, Kaneko H, Hishikawa T, Sekigawa I, lida N et al. Effect of extremely low dose cyclosporine treatment on the thrombocytopenia in systemic lupus erythematosus. Lupus, 1998;7:53-6.

[286] Ahn YS, Harrington WJ, Seelman RC, Eytel CS. Vincristine therapy of idiopathic and secondary thrombocytopenias. N Engl J Med, 1974;291:376-80.

[287] Roldan R, Roman J, Lopez D, Gonzalez J, Sanchez C, Martinez F. Treatment of hemolytic anemia and severe thrombocytopenia with high-dose methylprednisolone and intravenous immunoglobulins in SLE. Scand J Rheumatol, 1994;23:218-9.

[288] Chandramouli NB, Rodgers GM. Prolonged immunoglobulin and platelet infusion for treatment of immune thrombocytopenia. Am J Hematol, 2000;65:85-6.

[289] Maier WP, Gordon DS, Howard RF, Saleh MN, Miller SB, Lieberman JD et al. Intravenous immunoglobulin therapy in systemic lupus erythematosusassociated thrombocytopenia. Arthritis Rheum, 1990;33:1233-9.

[290] Levy Y, Sherer Y, Ahmed A, Langevitz P, George J, Fabbrizzi F et al. A study of 20 SLE patients with intravenous immunoglobulin--clinical and serologic response. Lupus, 1999;8:705-12.

[291] ter Borg EJ, Kallenberg CG. Treatment of severe thrombocytopenia in systemic lupus erythematosus with intravenous gammaglobulin. Ann Rheum Dis, 1992;51:1149-51.

[292] Maeshima E, Kida Y, Goda M, Minami Y. A case of systemic lupus erythematosus expressing intractable thrombocytopenia remedied effectively by intermittent and continuous administrations of a small amount of immune globulin. Mod Rheumatol, 2006;16:239-42.

[293] You YN, Tefferi A, Nagorney DM. Outcome of splenectomy for thrombocytopenia associated with systemic lupus erythematosus. Ann Surg, 2004;240:286-92.

[294] Coon WW. Splenectomy for cytopenias associated with systemic lupus erythematosus. Am J Surg, 1988;155:391-4.

[295] Hakim AJ, Machin SJ, Isenberg DA. Autoimmune thrombocytopenia in primary antiphospholipid syndrome and systemic lupus erythematosus: the response to splenectomy. Semin Arthritis Rheum, 1998;28:20-5.

[296] Kneitz C, Wilhelm M, Tony HP. Effective B cell depletion with rituximab in the treatment of autoimmune diseases. Immunobiology, 2002;206:519-27.

[297] Chen $H$, Zheng W, Su J, Xu D, Wang Q, Leng X et al. Low-dose rituximab therapy for refractory thrombocytopenia in patients with systemic lupus erythematosus--a prospective pilot study. Rheumatology (Oxford), 2011;50:1640-4.

[298] ten Cate R, Smiers FJ, Bredius RG, Lankester AC, van Suijlekom-Smit LW, Huizinga TW et al. Anti-CD20 monoclonal antibody (rituximab) for refractory autoimmune thrombocytopenia in a girl with systemic lupus erythematosus. Rheumatology (Oxford), 2004;43:244. 
[299] Lehembre S, Macario-Barrel A, Musette P, Carvalho P, Joly P. [Rituximab treatment for immune thrombocytopenia associated with systemic lupus erythematosus]. Ann Dermatol Venereol, 2006;133:53-5.

[300] Fukushima T, Dong L, Sakai T, Sawaki T, Miki M, Tanaka M et al. Successful treatment of amegakaryocytic thrombocytopenia with anti-CD20 antibody (rituximab) in a patient with systemic lupus erythematosus. Lupus, 2008;17:210-4.

[301] Lateef A, Lahiri M, Teng GG, Vasoo S. Use of rituximab in the treatment of refractory systemic lupus erythematosus: Singapore experience. Lupus, 2010;19:765-70.

[302] Feinglass S, Deodhar A. Treatment of lupus-induced thrombocytopenia with recombinant human interleukin-11. Arthritis Rheum, 2001;44:170-5.

[303] Maroun MC, Ososki R, Andersen JC, Dhar JP. Eltrombopag as steroid sparing therapy for immune thrombocytopenic purpura in systemic lupus erythematosus. Lupus, 2015;24:746-50.

[304] Alkaabi JK, Alkindi S, Riyami NA, Zia F, Balla LM, Balla SM. Successful treatment of severe thrombocytopenia with romiplostim in a pregnant patient with systemic lupus erythematosus. Lupus, 2012;21:1571-4. 